\title{
HIGHLY VALUED EQUITY AND REAL OPERATION MANAGEMENT: LONG-TERM “DETOXIFICATION”
}

\author{
Chau Minh Duong ${ }^{1}$
}

\begin{abstract}
This paper find evidence that in five years after being highly valued, firms consistently manage earnings downwards via spending more discretionary expenses and underproduction. Moreover, I find that such income-decreasing real operation management is only observable when the high valuation is firm-specific but not when the market highly values the whole industry. My long-term real operation management evidence is, therefore, in line with the signaling hypothesis which predicts highly valued firms would manipulate earnings downwards as a signal to correct the market. Put together with the short-term opportunistic income-increasing accruals management, the general picture is in line with a scenario where highly valued firms signal to correct the market in long-term while trying to avoid an immediate price correction in short-term.
\end{abstract}

Keywords: Earnings management, real operation management, highly valued equity, market mispricing.

\footnotetext{
1 Faculty of Business and Management, Canterbury Christ Church University, Email: c.m.duong41@canterbury.ac.uk. I gratefully acknowledge useful discussions and comments from the participants of the 2010 BAA Doctoral Colloquium, the 2010 EFMA's "Merton H. Miller" Doctoral Program and the 2010 FMA European Doctoral Student Consortium. This paper is particularly benefited from useful discussions with Gioia Pescetto, Daniel Santamaria, Steven Young, William Rees, Andrew Stark, Brian SingletonGreen, Alan Goodacre, Martin Walker, Gordon Alexander, Lawrence Kryzanowski, Philip Gharghori, J. Henk von Eije, Lorne Switzer, Marta Gomez-Puig, Christian Riis Flor, Alexander Subbotin. All remained errors are my own.
} 


\section{INTRODUCTION}

In a world where we could observe more and more multi-billion dollar firms going bankrupt after long periods of having unrealistically high market price, it is very important that we understand what is happening behind the scenes. This paper contributes to such understanding by investigating how highly valued firms engage in long-term real earnings management. The investigation is motivated by the influential agency cost theory of overvalued equities recently proposed by Jensen (2005) which predicts that substantially overvalued firms would exercise income-increasing earnings management opportunistically in attempts to maintain the overvaluation. As inflating earnings could lead to even more severe overvaluation, which in turns would require even more earnings manipulation in the next period, Jensen (2005) describes this scenario as "addicts" could not give up the "heroin" despite they all know "massive pain lies ahead". Most of the existing literature generally confirm Jensen's opportunistic hypothesis (e.g. Chi and Gupta, 2009; Houmes and Skantz, 2010). However, the existing studies only ask how overvalued firms engage in accruals management in the year immediately following market overvaluation while they are silent regarding how those firms manipulate real earnings in long-term. This paper aims at filling this gap of the literature.

Jensen's (2005) agency cost is not the only theory predicting earnings management behaviours of overpriced firms. There is another stream of the literature suggesting that earnings management could make earnings more informative because it is the channel through which managers can signal their private information to the market (e.g. Subramanyam, 1996; Gunny, 2009). Under the signalling hypothesis, it could be expected that overpriced firms would try to depress earnings via earnings management as the signals to correct market mispricing, an empirical prediction that is contradictory to Jensen's story. Despite being very interesting, the signalling hypothesis has not yet been directly tested in the context of overpriced firms. 
This paper makes an interesting contribution to the literature by testing the signalling hypothesis in the context of highly valued firms. In Jensen's words, my question is whether the "early stage addicts", when it is still possible, try to "detoxify"? Jensen (2005) emphasizes that his story is only applicable to substantially overvalued firms, which he defines as those whose market price exceeds the underlying value by as much as $100 \%$ or even $1000 \%$. However, none of the empirical models employed in the extant literature seems capable of really identifying such firms. At best, given the limitations of valuation models and data, empirical studies could only identify a larger group of firms whose market valuation are relatively higher than others (which could probably contain some substantially overvalued ones), which could be better referred to as highly valued firms. Substantially overvalued firms, by definition, need a huge price correction if they want to adjust stock price to the "normal" level. And, as Jensen argues, the consequences of large price reduction are so painful that managers often try to maintain the current stock price rather than try to adjust the price back to a more reasonable level. The key difference of highly valued firms as compared to substantially overvalued firms is most highly valued firms still have the option to correct the market by taking measures to reduce its stock price because the overvaluation is not yet too severe. Therefore, focusing the attention to a larger group of firms with relatively high market valuation could create an interesting setting to test the opportunistic versus the signalling hypothesis.

Jensen $(2005, \mathrm{p} 10)$ suggests that "there has simply been no listening in the boards" for manager's arguments that the firm should try to reduce its stock price. While this point makes absolute sense, it is doubtful that there is no other way round. I believe the signalling behaviours cannot be observed by looking at accruals management in the short-term. Instead, managers would correct the market in a safer and more controllable way through, for example, the mechanism of real earnings management over a longer period. First, a sudden price drops could have severe consequences for managers. Therefore, signalling behaviours, if any, should only be observed over the long-term while in short-term 
opportunism is still predominant. Second, among different strategies to manipulate earnings, real earnings management is the most likely to be used for this purpose because (1) accruals management could not be used in long-term due to its reversal nature, and (2) real earnings management is hard to be detected due to the complex nature of business judgements. Therefore, this paper concentrates on the long-term real earnings manipulation by highly valued firms.

This paper finds very interesting and important evidence that in up to five years after being highly valued, firms consistently try to depress earnings via real operation management, which is in line with the signalling hypothesis. Specifically, highly valued firms tend to spend more discretionary expenses and produce less as compared to others. Put together with existing evidence of income-increasing accruals management in the year immediately after being highly valued (e.g. Chi and Gupta, 2009; Houmes and Skantz, 2010), my evidence suggests an interesting equilibrium story where highly valued firms pursue correcting the market in long-term but try to avoid a sudden price drop in short-term. Such story is a large step towards a more thorough knowledge of how highly priced firm manipulate earnings. Moreover, by following Rhodes-Kropf et al. (2005) to decompose market valuation errors into firm-specific and industry-level components, the paper also finds that while market high valuation appears to be a strong motivation for real operation management, firms seem irresponsive if the high valuation is at industry-level rather than firm-specific. In addition, most of the findings are found to be robust across different approaches to indentify highly valued firms.

This paper is the first that develops testable predictions to investigate the signalling behaviours of highly valued firms. The story I propose is very interesting and could make significant contributions. The paper could also gain a lot of attention from both academics and practitioners. First, given the contradictory predictions of the two influential theories, an equilibrium that links the opportunism with signalling behaviours could receive substantial attention from the academic community, especially under the growing evidence in support of 
Jensen's opportunistic story recently. Second, the knowledge about how highly valued firms manipulate earnings is of crucial interests to market participants because highly valued firms are typically those which receive the most attention from the market. Third, the insights gained from this paper are especially useful to investors to make more informed investment decisions, especially those whose trading activities target mispriced stocks. Last but not least, the paper also provides useful implications for the boards and audit committees suggesting that they should perform their supervisory duties with higher care when the firms are becoming more highly valued.

The rest of this paper proceeds as follows. Section II briefly reviews the related literature to locate the niche of the paper before the testable hypotheses are motivated and developed. Section III describes the data and main methodologies. Section IV presents and discusses the results while section $\mathrm{V}$ concludes the paper.

\section{RELATED LITERATURE, MOTIVATIONS AND HYPOTHESES}

\section{II.1. Related literature ${ }^{2}$}

Although there are quite a number of earnings management methods recognised in the literature, two of them receive the lion's share of attention. First, the most popular method is accruals management where managers exercise their discretion over the choices of accounting policies and estimations to affect earnings. Second, managers can make supoptimal real operation decisions to manipulate earnings. Graham et al. (2005) provide survey evidence that managers prefer real operation management to accruals management. Although there is no agreement in the literature as to a standard model of real operation management, many types of real operation management have been recognised. Roychowdhury (2006) finds that managers may offer discounts to boost sales, over-produce to lower cost of goods sold, or reduce discretionary expenses (such as research and development or advertising expenses) in attempts to avoid reporting losses. Gunny (2009)

\footnotetext{
${ }^{2}$ Please refer to Ronen and Yaari (2008) for a very good review of this literature.
} 
finds that to manipulate earnings to meet earnings benchmarks, beside the three methods investigated by Roychowdhury (2006) managers can also manipulate the timing of long-lived assets sales and investment or change sales price. Moreover, there is also a growing body of the literature studying accruals and real operation management together. Cohen et al. (2008) find that the Sarbanes-Oxley Act, passed in 2002, diverts US firms from managing accruals towards real operation management. Cohen and Zarowin (2008) find a relation between both accruals management and real operation management with investment activities. Zang (2007) finds that accruals and real operation management are used as substitutes and suggests that real operation management is determined before accruals management. Athanasakou et al. (2009b) find that, in competition with classificatory shifting and earnings guidance, UK firms are less likely to use accruals and real operation management in attempts to achieve analyst forecasts.

Motives to manage earnings can be grouped into two main categories. First, earnings can be opportunistically managed, such as to meet earnings benchmarks, to maximise manager's benefits from stock compensation, or depress price prior to, for example, a management buyout (Perry and William, 1994; Teoh et al., 1998a\&b; Cohen and Zarowin, 2010; Gore et al., 2007). Second, earnings management could be used to signal manager's private information to the market, and thus enhance the usefulness of earning figures (e.g. Subramanyam, 1996; Gunny, 2009).

There is a growing body of the literature examining capital market driven motivations for earnings management. Along this line, research has studied how managers respond to certain conditions/actions of the market. A recent stand of the literature has started to look at the role of market overvaluation as an earnings management motivation. The next section will analyze in details some gaps of this body of the literature to motivate this research. 


\section{II.2. Why study long-term real operation management by highly valued firms?}

Jensen (2005) predicts that substantially overpriced firms would employ earnings-increasing strategies to sustain the overvaluation. This is the key paper that provides a testable theoretical framework to motivate empirical studies on market overvaluation as a motivation for firms to manipulate earnings. Sawicki and Shrestha (2008) compare abnormal accruals across different quintiles of firms ranked by book-to-market ratio, and document no clear pattern suggesting that the level of accruals management is related to mispricing. Madhogarhia et al. (2009) find that growth firms manage earnings, in both directions, more aggressively than value firms, due to the more severe asymmetric information. Houmes and Skantz (2010) argue that managers may not necessarily always be aware whether their firms are overpriced or not. They therefore place their investigation on the groups of highly valued stocks and document that highly valued firms tend to use discretionary accruals to manage earnings upwards in the year following the firms being overpriced. Chi and Gupta (2009) measure firm-specific and industry-level valuation errors and find evidence that both measures are positively related to discretionary accruals in the year following the firms being overpriced. Badertscher (2008) also finds that among firms which have to restate their financial statements due to accounting irregularities, firms which have higher cumulative abnormal returns in the previous three years (termed as high overvalued firms) manage earnings upwards, using both accruals and real operation management, in three years prior to the restatement year.

Although the established evidence seems consistent with the agency cost theory of overvalued equity proposed by Jensen (2005), there are still a number of gaps. One of those gaps is related to the choices of earnings management mechanisms. Most of the existing studies concentrate on accruals management. However, ignoring the other options for manipulating earnings, such as real operation management, could potentially omit important aspects of the true decisions made by managers. This paper, therefore, firstly provides evidence of how highly valued firms manipulate real operations to fill this gap. 
The second gap of the literature is related to the identification of overpriced firms. Jensen emphasizes that his story is only applicable for substantially overvalued stocks. However, the identification of substantially overvalued stocks is very tricky ex ante and could not be done with complete accuracy. At best, currently available empirical approaches could only give us a sense of whether a firm is highly valued relatively to others. Therefore, this paper avoids a direct test of how substantially overvalued stocks manage earnings. Instead, I investigate the earnings management of highly valued firms, i.e. firms which are highly valued by the market relatively to others. Although this design leaves me with little to say about Jensen's conjectures, my concentration on highly valued firms provides an interesting setting where most of the firms investigated have not yet been "trapped" in the game of playing with earnings to justify the expectations which are, by definition of overvaluation, impossible. Highly valued firms can choose to satisfy the market by inflating earnings, but they also have the option to correct the market. Therefore, concentration on highly valued firms could allow the test between the opportunistic versus signalling behaviours, which are two of the most popularly perceived theories behind earnings management.

If managers of highly valued firms indeed desire to correct the market rather than try to maintain market high valuation, how could we explain the income-increasing accruals management documented in the extant literature (e.g. Houmes and Skantz, 2010, Chi and Gupta, 2009)? My guess is managers of highly valued firms could possibly try to avoid an immediate market correction, which could be too dangerous for the firm as well as for themselves in terms of job security and reputation. There are lots of evidence about market substantial penalty when firms, especially highly valued firms, fail to meet expectations by as much as pennies (e.g. Skinner and Sloan, 2002). Also, it is not difficult to imagine the anxious response of the boards, the analysts or even the whole market if the managers could not deliver what is expected. Therefore, the signalling behaviours, if any, should appear in longer terms in ways that are less obvious to the boards and the outsiders. This is where the third important gap of the literature lies. Most of the existing studies concentrate only on the 
year following the firms being highly valued, which leaves the long-term perspective another important gap of the literature. The reason why the extant literature only concentrates on the short-term could possibly be due to, among other things, the reversal nature of accruals management, i.e. if ones look at longer window, there should not be any evidence of accruals management. However, there are some alternative earnings management methods that could be employed consistently in long-term, one of which is real operation management. To fill this gap, this paper, therefore, investigates long-term real operation management activities.

\section{II.3. Hypotheses}

Overall, by referring to the extant literature the analysis so far fully motivates my investigation of how highly valued firms manipulate real operations in long-term. Such investigation can fill three important gaps of the literature regarding how mispriced firms manipulate earnings, which makes an important contribution to our understanding of this topical and crucial issue. For the empirical test, I predict highly valued firms to engage in real operation management in long-term to correct the market rather than to maintain the high valuation. If a firm is highly valued in a period, i.e. the market expectation is relatively high, and the firm tries to satisfy such relatively high expectation, what could most possibly happen in the next period is an even higher expectation. If it continues in long-term, the firm will end up being substantially overpriced. Jensen describes this scenario as "addicts" could not give up the "heroin". However, as all "addicts", and we all, know, the consequences are very painful. As outlined and evidenced by Jensen (2005), for the firm as a whole, substantially overvaluation will create huge value destruction, and for the managers personally, substantially overvaluation often means huge stresses, reputation damage or even risky legal breaches. So my first question is, in Jensen's words, whether the "early stage addicts", when it is still possible, try to "detoxify"? The first hypothesis is therefore designed to test whether in long-term managers signal to correct high market valuation via real operation management. 


\section{H1: In long-term, highly valued firms engage in income-decreasing real operation management.}

However, there are at least two causes of market high valuation that have different empirical predictions. A firm may be highly valued because the market highly values it relatively to other firms, or simply because it belongs to an industry which is highly valued. Ex ante, it is rational to expect if managers do indeed manipulate real operations to correct the market, the attempts will be made towards the firm-specific rather than industry-level misevaluation because when an entire industry is mispriced, actions from individual firms seem incapable to correct the market. Consequently, I hypothesize:

H2: In long-term, any real operation management of highly valued firms is due to firm-specific valuation errors rather than industry-level valuation errors.

\section{DATA AND METHODOLOGIES}

\section{III.1. Sample selection}

This study uses the sample of all UK ordinary stocks which are listed on the London Stock Exchange during the period 1995-2004. For the purpose of this research, the UK market during such period provides a very interesting setting. The debate regarding the choices of earnings management methods by UK firms in relation to capital market driven motivations is ongoing and attracts a lot of attentions. There is some recent evidence that UK firms are less likely to use accruals and real operation management in order to meet analyst forecasts (e.g. Athanasakou et al., 2009a\&b). Therefore, any evidence of real operation management in relation to market valuation could add more insights to the debate. Moreover, although research on real operation management has emerged reasonably well in North America during the late 2000s, there is limited evidence on real operation management in the UK, and far more limited evidence on the link between real operation management and market 
mispricing. The sample excludes the pre-FRS1 period to ensure reasonable data availability, especially in relation to cash-flow-related variables ${ }^{3}$, and ends at 2004 to allow the follow-up in five years after the last period considered. Such period also fits very well within the period when FRS 3 was in force (i.e. since its issuance in 1993 until the adoption of IFRS by UK firms in 2005), which could hold one of the main market-wide constraints on accruals management constant. This feature of the data is important because part of real operation management is possibly determined by how easily accruals management could be exercised (e.g. Zang, 2007) and there are substantial evidence that firms would be more interested in real operation management during period of increased accounting regulatory controls (e.g. Cohen et al., 2008).

All data are downloaded from Datastream and Worldscope databases. To avoid survivorship bias, both live and dead stocks are selected. Similar to the common practice in this area, financial and utility firms are excluded. Stocks that have more than one type of ordinary shares are also excluded to avoid problems with apportioning firm-level earnings to each type of shares. This creates a general sample which is used to estimate the proxies for real operation management (section III.2), market valuation errors (section III.3), abnormal investments and benefits of discretionary expenditures (section III.4).

The final sample used in the main test is derived after applying a few more restrictions. First, stocks whose market-to-book ratios are negative are excluded to avoid problems associated with interpreting negative book value in terms of market valuation. Second, to avoid tiny stocks that could potentially inflate the scaled variables, stocks whose either beginning total asset or market value is less than 1 million pounds and those whose market price as at fiscal year-end dates is below 25 pence are also dropped. Finally, after imposing data availability criterion, the final sample comprises of 2,147 firm-year observations. All continuous variables are winsorized at the $1^{\text {st }}$ and $99^{\text {th }}$ percentiles to mitigate the influence of outliers.

\footnotetext{
${ }^{3}$ Worldscope's cash flow data is very limited prior to the effective date of FRS 1 (Revised 1996).
} 


\section{III.2. Proxies for real operation management}

Within this paper, the term long-term earnings management refers to the engagement in certain earning management methods in a consistent way over a long period of time. As such, any inconsistent behaviour in shorter terms would not be regarded as long-term earnings management. For example, an abnormally high level of discretionary expenses in a certain year is not an evidence of long-term real operations management, unless it is followed consistently by abnormally high levels of discretionary expenses in some years thereafter. Under this definition, the available options to manipulate earnings in long-term is more limited as compared to in short-term because accruals manipulation could not be used due to its reversal nature. Among the other major earnings management methods identified by the current literature, this paper concentrates on three methods of manipulation real operations as proposed by Roychowdhury (2006), namely sales, discretionary expenses and production manipulation.

To empirically proxy for sales, discretionary expenses and production manipulation, I follow Roychowdhury (2006), where the regressions are run within each (two-digit SIC code) industry-year with at least 10 observations. Roychowdhury's (2006) measures of abnormal cash flow and abnormal discretionary expense are multiplied by -1 to derive at my measure of abnormal cash flow (Ab_CF) and abnormal discretionary expense (Ab_DEX). Abnormal production cost (Ab_PROD) is the same as Roychowdhury's (2006). As explained by Roychowdhury (2006), if actual cash flows and discretionary expenses are abnormally lower than the normal levels, it is an indicator of upward earnings management. Therefore, I multiply Roychowdhury's (2006) measures by -1 to make positive Ab_CF and Ab_DEX indicators of upward earnings management. For production costs, an abnormally high (low) level of Ab_PROD is an indicator of overproduction (underproduction), thus implies upward (downward) earnings management. 
I also create a measure of total real operation management, SRM_TOTAL, which is the sum of the standardized Ab_CF, Ab_DEX and Ab_PROD, where the standardized variables are calculated as follows:

$$
X_{i, t}^{s}=\frac{X_{i, t}-\bar{X}_{t}}{\sigma_{t}}
$$

where $X_{i, t}^{S}$ represents the standardized Ab_CF, Ab_DEX and Ab_PROD of firm $i$ in year $t ; X_{i, t}$ is Ab_CF, Ab_DEX and Ab_PROD of stock $i$ in year $t ; \bar{X}_{t}$ and $\sigma_{t}$ are the cross-sectional mean and standard deviation, respectively, of Ab_CF, Ab_DEX and Ab_PROD in year $t$. By construction, the standardized proxies will have a cross-sectional mean of zero and standard deviation of one. Therefore, this measure of total real operation management is free from any severe influence caused by a dominant component, if there is one.

\section{III.3. Identification of highly valued firms}

Ex ante, the identification of mispriced firms could be tricky. From the market's view, unless there is a perfect valuation model and the market has all relevant information, it could be severely problematic in identifying mispriced stocks. Those issues make it empirically difficult to design a test to directly test the behaviours of mispriced stocks. Jensen emphasizes that his story is applicable only among severely overvalued stocks. Houmes and Skantz (2010) argue that managers of highly valued firms would act in a similar way as managers of overvalued firms. They provide evidence that firms employ income-increasing accruals management in the year following the firm being highly valued. This paper does not attempt to directly test Jensen's hypothesis about how substantially overpriced firms manage earnings. Instead, the paper concentrates on firms with high market valuation relatively to other firms in the same industry. First, this design allows me to avoid the tricky task of empirically identify mispriced stocks, which as explained above could not be practically done

with complete accuracy. Second and more important, highly valued stocks have an appealing characteristic that is suitable for my long-term test (that substantially overvalued stocks do not have), which is they have not been "trapped" in the "game" of overvaluation 
(which is, as argued by Jensen, hard to escape), thus they can make the choice to maintain high market valuation or to correct the market.

Although the market-to-book ratio is widely used in the literature as an empirical proxy for market misevaluation, it is a noisy proxy because it can also capture other factors, such as growth opportunities or the level of intangible assets (which is not recorded in book values). Rhodes-Kropf et al. (2005) argue that market-to-book ratio comprises of three components capturing intangible values, valuation errors and growth opportunities. Moreover, RhodesKropf et al. (2005) also decompose valuation errors into two sup-components, one capture firm-specific and the other capture industry-level valuation error. Chi and Gupta (2009) employ Rhodes-Kropf et al. (2005) approach to identify overvalued firms and find that overvalued firms manipulate earnings upward via accruals management. Chi and Gupta (2009) also find evidence that the valuation error components of the market-to-book ratio can indeed capture some market mispricing as the strategies that take long in underpriced stocks and short in overpriced stocks can generate significant abnormal returns in up to three years after portfolio formation.

This paper employs Rhodes-Kropf et al. (2005)'s decomposition approach to identify highly valued firms. This approach is particularly appropriate for my test for at least two reasons. First, the levels of some real operation activities, such as research and development expenses, advertising expenses, production levels etc., are related to the firm's growth opportunities, which are usually proxied for by market-to-book ratio. Therefore, if market-tobook ratio is also used to identify highly valued firms, there will be some multicollinearity in the ordinary regression, which could inflate the standard errors of the interested coefficients. Instead, I only use the components of the market-to-book ratio that capture valuation error to identify highly valued firms, while the component of the market-to-book ratio that capture growth opportunities is used as a control variable. This approach is, therefore, free from the problem of multicollinearity while I can still appropriately control for the cross sectional variation in growth opportunities. Second, separating between firm-specific from industry- 
level valuation errors can enable the investigation of which source of market misevaluation really drives firm's earnings management (i.e. test of $H 2) .{ }^{4}$

I follow Rhodes-Kropf et al. (2005) to estimate firm-specific valuation errors (FVE), industrylevel valuation errors (IVE) and value-to-book ratio (VB) as a proxy for growth opportunities, where the long-run industry valuation multiples are averages over the 1990-2008 period ${ }^{5}$. I also define total valuation errors, denoted TVE, as the sum of FVE and IVE. Highly valued firms are then identified using FVE, IVE and TVE as follows. First, for each industry-year, all observations with positive values of FVE are ranked into five quintiles and the indicator of firms with high firm-specific valuation errors (denoted FHV) is defined as a dummy variable that takes the value of one if the observation is in the highest quintile and zero otherwise. Similarly, the same process is then repeated using (i) IVE to construct IHV, which is the indicator of firms with high industry-level valuation error, and (ii) TVE to construct THV, which is the indicator of firms with high total valuation errors.

\section{III.4. Control variables}

In the regression tests, I include as control variables many factors that have been identified in prior studies as being able to affect the cross-sectional variance of the proxies for real operation management. The justifications and measurement of those control variables are explained in this section. Because all proxies for real operation management are measured within industry, any control variable that is not measured within industry is calculated as deviation from the respective industry-year median before entering the regression. I use the italic lower case letter ' $a$ ' as a prefix to the concerned variables to denote industry-adjusted variables (e.g. aSIZE refers to market value measured as deviation from the corresponding industry-year median).

\footnotetext{
${ }^{4}$ Market mispricing can arise for many reasons and could exist regardless of whether the market is efficient or inefficient. Although the approach employed here does not allow the test to separate between different causes of mispricing, the approach is still suitable for this paper given the objective is to see how mispricing, once established, could affect manager behaviours rather than to identify the causes of mispricing.

${ }^{5}$ Details of the estimation can be available upon request.
} 


\section{(i) Size, Growth Opportunities and Profitability}

Firms with different size face different levels of pressures, costs and incentives to manipulate earnings (e.g. Watts and Zimmerman, 1990). Besides, real operations, especially production activities and investments, could be dependent on the levels of growth opportunities. Moreover, due to the established evidence that abnormal accruals measures are correlated

with profitability (e.g. Dechow et al., 1995 etc.), it is not unnecessary to control for profitability when examining real operation management. Indeed, most of previous studies on real operation management control for size, growth opportunities and profitability (e.g. Roychowdhury, 2006; Zang, 2007; Badertscher, 2008 etc.), although the evidence seems to be inconsistent across studies. I follow the established literature to also control for these factors. To proxy for size, I use log of firm's market value at fiscal year-end, which enters the regression as deviation from the corresponding industry-year median (denoted as aSIZE). Growth opportunities are proxied for by the true value-to-book ratio (VB, measured as described in section III.3). To proxy for profitability, I use industry-adjusted returns-on-assets ratio $(a R O A)$, where $R O A$ is calculated as net income available to common shareholders scaled by beginning total assets. Since there is no consistent evidence in the existing literature regarding the sign of these factors, I make no prediction.

\section{(ii) Leverage}

It is well understood that debts usually come with restrictions, which in turn are often tied to the firm's performance. Therefore, firms with higher leverage have more pressures to engage in income-increasing earnings management (e.g. Houmes and Skantz, 2010). I control for leverage using aLEV, where LEV is the ratio of total liabilities to total assets. aLEV is predicted to be positively related to the proxies of real operation management.

\section{(iii) Net Operating Assets}

Zang (2007) suggests that real operation and accruals are managed as substitutes. Therefore, the level of real operation management in the current period is partly determined 
by the firm's ability to engage in accruals management. However, including a proxy for accruals management in the regressions may cause serious problems of endogeneity because the level of accruals management is also determined by the level of real operation management. Instead, I indirectly control for the level of accruals management by using an exogenous measure of the firm's ability to engage in accruals management, which is net operating asset. Due to the articulation between the income statement and the balance sheet, net operating asset is a measure of the firm's past accruals management activities. Thus, because accruals will, by nature, reverse eventually, net operating asset is a good measure of the constraints for the firm to engage in further accruals management (Barton and Simko, 2002). Houmes and Skantz (2010), among others, document a strong relationship between discretionary current accruals and beginning net operating assets. I, therefore, use aBLOAT to control for the firm's ability to engage in accruals management, where BLOAT is measured as shareholder's equity plus total debts minus cash and shortterm investment scaled by sales. Because higher net operating asset will constraint accruals management, which in turn implies more real operation management, I predict aBLOAT to have positive sign.

\section{(iv) Level of Competitiveness}

Deviation from optimal business decision does not come without costs. Depending on which industry a firm is in and how competitive it is relatively to others in the industry, such costs vary. More specifically, firms in less competitive industries and firms which are more relatively competitive (usually due to their big size so that they can enjoy the economy of scale and/or more bargaining power) face lower costs for manipulating real operation. I follow Zang (2007) to use the Herfindahl index (denoted as HERFINDAHL) to proxy for the level of competition in the industries. Each year, HERFINDAHL is calculated as the sum of squared market share of all firms in the industry, where market share of a firm is its sales scaled by the total sales of all firms in the industry. HERFINDAHL is, therefore, an industry-wide

measure that is shared by all firms in a given industry-year. Moreover, to proxy for the firm 
industry-relative competitiveness, I also follow Zang (2007) to calculate M_SHARE as the percentage of a firm's sales to the total sales of its industry. Because low industry-level competitiveness and high firm-specific relative competitiveness could make it less costly to manipulate real operations, in both directions, I predict HERFINDAHL and M_SHARE to be significant in the regression, but make no prediction regarding their signs.

\section{(v) Financial Distress}

Zang (2007) argues that it is more costly for financially distressed firms to manipulate real operations. She indeed documents a strong relationship between an indicator of distressed firms and different proxies for real operations management. Following this line of argument, I also control for financial distress by using Taffler's (1983) UK version of Z_SCORE to identify distressed firms. Specifically, I measure Z_SCORE as:

$$
Z_{-} S C O R E=3.2+12.8 x_{1}+2.5 x_{2}-10.68 x_{3}+0.029 x_{4}
$$

where: $x_{1}$ is pre-tax incomes scaled by current liabilities; $x_{2}$ is current assets scaled by total liabilities; $x_{3}$ is current liabilities scaled by total assets; $x_{4}$ is no-credit interval, measured as quick assets minus current liabilities scaled by daily operating expenses, where daily operating expenses is sales minus pre-tax incomes minus depreciation expenses divided by 365.

Agarwal and Taffler (2007) shows that over the period from 1979 to 2003 , about $96 \%$ of failed firms have negative Z_SCORE based on their last published financial statements. Using the zero threshold as suggested, I define the dummy DISTRESS to identify distressed firms as having the value of one if the firm's lagged Z_SCORE is negative, and zero otherwise. Because being distressed would make it costly to engage in real operations management, in both directions, I predict the coefficient of DISTRESS to be significant but make no prediction regarding its sign.

\section{(vi) Big Bath Practice}


The big bath practice refers to extreme earnings management behaviours where managers intentionally book huge losses into the current period, possibly in attempts to boost future earnings. It is well documented that firms tend to take large write-offs in periods when the managers found it hard to avoid a loss anyway (e.g. Christensen et al., 2008). I control for this practice by introducing two control variables that identify firms which are more likely to engage in big bath accounting. The first variable, LOSS_FIRM, is a dummy which is one if a firm's net income is negative, and zero otherwise. The second variable, LOSS_IND, is a dummy which is one if the average net income of all firms in an (two-digit SIC) industry is negative, and zero otherwise. I predict LOSS_FIRM and LOSS_IND to be negatively related to the proxies of real operations management.

\section{(vii) Equity Issuance}

There is substantial evidence that firms manipulate earnings upward during seasoned equity offers via accruals management (e.g. Teoh et al., 1998b). Although the existing literature is silent regarding whether real operation management could be the option for issuers to manipulate earnings, controlling for this capital-driven motivation when modelling real operations management seems necessary due to evidence that accruals and real operation management are used as substitutes (e.g. Zang, 2007). I follow Zang (2007) to introduce a dummy variable, SEO, which is one if a firm issues common equity in the last three years (including the current year), and zero otherwise. For a firm to be identified as equity issuer in a year, I require (i) its proceeds from sale/issuing stocks to be positive, and (ii) its number of outstanding common shares to increase by at least $1 \%$ since last year. I predict SEO to be positively related with the proxies for real operation management.

\section{(viii) Fixed Costs}

One of the three real operation management activities examined in this paper, the production cost manipulation, is closely related to the intensity of the fixed cost component of production cost. If fixed cost component is higher relatively to variable component, varying the level of 
production could result in larger variation in earnings. I control for this using aPPE_SALES, where PPE_SALES is measured following Zang (2007) as the ratio of net plant, property and equipment to sales. APPE_SALES only enters the regression when Ab_PROD or SRM_TOTAL is the dependent variable. I predict aPPE_SALES to be significant in the regression, but make no prediction regarding its sign.

\section{(ix) Excess Investment}

Recent empirical researches provide strong evidence that earnings management is related to investment. Kedia and Philippon (2009) and McNichols and Stubben (2008) find that firms which are ex post earnings manipulators overinvest in the period of misreporting. Cohen and Zarowin (2008) find similar evidence for firms which are suspected to engage in either accruals or real operation management. I introduce a measure of excess investment (denoted Ab_INV) to control for this association. Prior researches (e.g. McNichols and Stubben, 2008; Cohen and Zarowin, 2008; Biddle et al., 2009 etc.), suggest that the level of normal investment is a function of investment opportunities and firm's liquidity. I use the value-to-book as a proxy for investment opportunities. For liquidity, I employ three proxies, including (i) book leverage, (ii) cash slack and (iii) operating cash flows. More specifically, I estimate the following regression within each industry-year with at least 10 observations:

$$
\frac{I N V_{i, t}}{A_{i, t-1}}=\alpha+\beta_{1} V B_{i, t-1}+\beta_{2} L E V_{i, t-1}+\beta_{3} S L A C K_{i, t-1}+\beta_{4} \frac{C F O_{i, t}}{A_{i, t-1}}+\varepsilon_{i, t}
$$

where: $I N V_{i, t}$ is investment of firm $i$ in year $t$, measured as capital expenditures plus research and development expenses minus proceeds received from fixed assets sales; $A_{i, t-1}$ is total assets at the end of year $t-1$ of firm $i ; V B_{i, t-1}$ is value-to-book ratio of the firm $i$ at the end of year $t-1$, measured as described in section III.3; $L E V_{i, t-1}$ is book leverage of firm $i$ in year $t$ -1 , defined as the ratio of total liabilities to total assets; $S L A C K_{i, t-1}$ is the ratio of cash and short-term investment to net property, plant and equipment of firm $i$ in year $t-1 ; C F O_{i, t}$ is net operating cash flows of firm $i$ in year $t$. The regression is run using a sample of all UK 
ordinary stocks which are listed on the London stock exchange with all data required, excluding financial, utilities firms and firms with more than one type of ordinary shares.

For each observation, the "normal" level of investment is calculated as the predicted value of (15) using the estimated coefficients from the corresponding industry-year regression. Abnormal investment (Ab_INV) is then computed as deviation from "normal" level of investments. I expect Ab_INV to exhibit a significant relationship with the proxies for real operation management, but I do not predict its sign.

\section{(x) Benefits of Discretionary Expenses}

Lev and Sougiannis (1996) provide evidence that research and development expenses positively relates to future earnings. Green et al. (1996) also find that research and development expenses are value-relevant in stock valuation. Therefore, deviation from the optimal level of research and development expenses seems costly to firms in terms of future benefits and market appreciation. To control for this, I base on Lev and Sougiannis (1996) model to develop an empirical proxy for the forgone current and future benefits resulting from cutting discretionary expenses. Lev and Sougiannis (1996) map current and past research and development expenses to current operating income to construct a measure of how much current earnings are forgone if $\$ 1$ of past or current research and development expenses is cut. First, I generalize Lev and Sougiannis's (1996) findings to other discretionary expenses, i.e. I assume that cutting other discretionary expenses also has certain impacts on current and future earnings. Second, I limit my investigation to only the current and five lags of discretionary expenditures. This is quite a reasonable design because Lev and Sougiannis (1996) found that the benefits from research and development expenses last, depending on industries, from five to nine years ${ }^{6}$. Third, to avoid the problem of multicollinearity due to autocorrelation of discretionary expenses, I use a measure of discretionary expenses that is cumulated over the last six years rather than putting six individual (possibly highly correlated)

\footnotetext{
${ }^{6}$ Moreover, as the period of this study starts from 1995, using more lags would lead to serious Datastream's data availability problem.
} 
variables into the regression. In particular, I estimate the following model within each industry-year with at least 10 observations:

$$
\frac{o I_{i, t}}{R E V_{i, t}}=\alpha+\beta_{1} \frac{A_{i, t-1}}{R E V_{i, t-1}}+\beta_{2} C D E X_{i, t-5} \text { to } t+\varepsilon_{i, t}
$$

where: $O I_{i, t}$ is operating income before depreciation and discretionary expenses (where discretionary expense is defined as the sum of research and development and selling and general administrative expenses) of firm $i$ in year $t, R E V_{i, t}$ is sales of firm $i$ in year $t ; A_{i, t-1}$ is

total assets at the end of year $t-1$ of firm $i$; $C D E X_{i, t-5}$ to $t$ is the accumulation of scaled discretionary expenses of firm $i$ from year $t-5$ to year $t$, where scaled discretionary expense is the sum of research and development and selling and general administrative expense scaled by sales. The regression is estimated using a sample of all UK ordinary stocks which are listed on the London stock exchange with all data required, excluding financial, utilities firms and firms with more than one type of ordinary shares.

The estimated coefficient on $C D E X_{i, t-5}$ to $t$ from equation (4) (i.e. the $\hat{\beta}_{2}$ ) is then denoted as DEX_BENEFIT and is used to proxy for the current and future benefits forgone by firms cutting discretionary expenditures. Because equation (4) is run within each industry-year, DEX_BENEFIT is an industry-wide measure which is shared by all firms in the same industry. DEX_BENEFIT only enters the regression where Ab_DEX or SRM_TOTAL is the dependent variable. I expect that firms with higher DEX_BENEFIT would spend more discretionary expenses, which in turn leads to lower Ab_DEX or SRM_TOTAL.

\section{DESCRIPTIVE STATISTICS AND EMPIRICAL RESULTS}

\section{IV.1. Descriptive statistics}

Table 1 reports the main statistics of the main variables for the final sample (column 2 to 4 ) and compares the means of highly valued firms (as defined by FHV, IHV and THV) with those of the rest of the sample (column 5 to 7,8 to 10 and 11 to 13 , respectively). For the whole sample, it could be noticed that the mean firm-specific and industry-level valuation 
errors are 0.033 and 0.059 , respectively ${ }^{7}$, which implies that on average more sample firms are highly valued. It can also be noted that the mean SRM_TOTAL is zero, implying that the standardization process is effective. The average Herfindahl index is quite low (0.154), taken together with low mean M_SHARE (0.001), the statistics imply the UK market is quite competitive. All of the industry-adjusted variables (i.e. aSIZE, aROA, aLEV, aBLOAT, aPPE_SALES) have median of zero as expected by construction. Overall, the descriptive statistics suggest no serious concerns and are comparable to other studies (e.g. Lara et al., 2009; Athanasakou et al., 2009a\&b).

\section{[INSERT TABLE 1 HERE]}

In comparison with the rest of the sample, highly valued firms exhibit some distinguishable characteristics. First, by construction, the mean FVE of FHV firms is significantly higher than the rest of the sample (0.682 compared to -0.046). Similarly, the mean IVE of IHV firms is also significantly higher than the rest of the sample ( 0.180 compared to 0.042$)$. However, it is interesting to note that the mean IVE of FHV firms and the mean FVE of IHV firms seems undistinguishable statistically as compared to the rest of the sample, suggesting FVE and IVE capture different dimensions of market misevaluation. Looking at the proxies for real operation management, the evidence suggests that highly valued firms tend to have lower Ab_DEX and Ab_PROD. This preliminary evidence is consistent with later tests suggesting highly valued firms on average engage in income-decreasing real operation management. Besides, highly valued firms also have significantly lower aROA and higher LOSS_FIRM (consistently across different indicators of highly valued firms), suggesting those firms, albeit being highly valued at the beginning of the year, in fact report lower profitability than others. Again, this preliminary evidence is in line with the signalling hypothesis. Moreover, it is also noticeable that highly valued firms are more likely to be common equity issuers in the last

\footnotetext{
${ }^{7}$ These two measures of valuation errors are not approximately zero because in estimating those valuation errors, I used a larger sample than the final sample used in the main tests.
} 
three years, consistent with existing evidence that the market overvalues firms with seasoned equity offers in the pre-issuing period (e.g. Loughran and Ritter, 1995).

Table 2 reports Pearson correlation coefficients of the main variables. Ab_PROD is positively related with both Ab_DEX (0.610) and Ab_CF (0.295), suggesting production manipulation is engaged simultaneously and in the same direction with discretionary and sales manipulation. However, the negative relation between Ab_DEX and Ab_CF $(-0.291)$ suggests that on average firms engage in discretionary expenses and sales manipulation in opposite directions (i.e. cutting discretionary expenses often goes with less price discounts and less lenient credit terms, and vice versa). FHV and IHV are positively correlated, but the correlation is small $(0.380)$ and statistically weak (only significant at $10 \%$ level). It, therefore, provides further evidence that FVE and IVE capture different dimensions of market misevaluation. It is also noted that FHV is negatively related to all measures of real operation management, except for Ab_CF (which is 0.029 but statistically insignificant), and the correlations between IHV and the proxies of real operation management are relatively weak. Such preliminary observation is in line with the evidence in the main tests, suggesting highly valued firms manage earnings downwards via discretionary expenses and production manipulation if the high valuation is firm-specific, but not if the market highly values the whole industry. Looking across the control variables, there seems to exist most of the correlations with the proxies for real operation management as predicted, and there is no significantly high correlation between the right hand side variables that could be potentially problematic.

\section{[INSERT TABLE 2 HERE]}

\section{IV.2. Portfolios analysis}

Within each industry-year, I first rank all firms with negative FVE in year $t-1$ into five quintiles (indexed from 1 to 5 ) and all firms with positive FVE in year $t-1$ into five quintiles (indexed from 6 to 10). The process is then repeated using IVE and TVE. Therefore, for each 
measure of market valuation errors, I have ten groups of stocks, indexed from 1 to 10 , of which group 1 includes stocks with the lowest market valuation and group 10 comprises of stocks that are most highly valued. Table 3 presents the means of the proxies for real operation management in year $t$ to $t+4$ across the 10 groups.

\section{[INSERT TABLE 3 HERE]}

Figure 1 illustrates graphically the patterns of real operation management engaged by firms with different levels of firm-specific evaluation errors (reported in Panel A of Table 3). While there seems to exist no clear pattern with regard to sales manipulation, the downward slopes of Ab_DEX and Ab_PROD are impressive. It suggests that as firm-specific misevaluation increases, firms tend to engage in real operation management activities that affect earnings more negatively. In fact, firms with the highest market valuation on average have remarkably lower Ab_DEX and Ab_PROD than those with the lowest market valuation. Such patterns lead to SRM_TOTAL also has the downward slope in Figure 1. In general, the evidence tends to suggest firm-specific market misevaluation is a real driver of real operation management and the affect is in line with the signalling hypothesis. Firms which are priced the lowest by the market try the most to inflate earnings while the most highly valued firms are associated with the most income-decreasing real operation management, which are both managers' signals to correct the market.

\section{[INSERT FIRGURE 1 HERE]}

Panel B of Table 3 presents similar results using industry-level valuation errors. When ranked by industry-level evaluation errors, there seems to be no clear pattern that suggests industry-level market valuation errors are related to real operation management. The evidence is therefore in line with industry-level market misevaluation does not induce real 
operation management. However, when aggregated with firm-specific misevaluation, Panel C still reports the monotonic relationships between total market misevaluation and Ab_DEX and Ab_PROD.

Overall, the evidence in this section strongly supports hypothesis $H 1$ and $H 2$. The advantage of portfolio analysis approach is it enables the patterns, if any, to reveal. However, portfolio analysis suffers from being unable to control for cross sectional differences in factors that could potentially affect the proxies for real operation management. This weakness will be reinforced in the regression analysis in the next section.

\section{IV.3. Main regression test}

In this section, I use the regression approach to compare the levels of real operation management engaged by highly valued firms with the rest of the sample. Specifically, the following regression is estimated:

$$
\begin{aligned}
& Y_{i, t+k}=\alpha+\beta_{1}\left(a S I Z E_{i, t-1+k}\right)+\beta_{2}\left(V B_{i, t-1+k}\right)+\beta_{3}\left(a R O A_{i, t+k}\right)+\beta_{4}\left(a L E V_{i, t-1+k}\right)+ \\
& \beta_{5}\left(\operatorname{aBLOAT}_{i, t-1+k}\right)+\beta_{6}\left(M_{-} S H A R E_{i, t+k}\right)+\beta_{7}\left(H_{E R F I N D A H L_{i, t+k}}\right)+ \\
& \beta_{8}\left(\operatorname{DISTRESS}_{i, t-1+k}\right)+\beta_{9}\left(\operatorname{LOSS}_{-} \text {IIRM }_{i, t+k}\right)+\beta_{10}\left(\operatorname{LOSS}_{-} I N D_{i, t+k}\right)+ \\
& \beta_{11}\left(S E O_{i, t+k}\right)+\beta_{12}\left(a P P E_{-} S A L E S_{i, t-1+k}\right)+\beta_{13}\left(A b_{-} I N V_{i, t+k}\right)+ \\
& \beta_{14}\left(D_{E X} \text { BENEFIT }_{i, t-1+k}\right)+\beta_{15}\left(\text { SUSPECT }_{i, t-1}\right)+\varepsilon_{i, t+k}
\end{aligned}
$$

where: $\mathrm{k}=0,1,2,3,4 ; \mathrm{Y}$ is replaced by Ab_CF, Ab_DEX, Ab_PROD, and SRM_TOTAL one after another; all the control variables are described in section III.4 (noted that aPPE_SALES (DEX_BENEFIT) is only used when Ab_PROD (Ab_DEX) is the dependent variable); for each dependent variable, SUSPECT is replaced by one of the indicators of highly valued firms as described in section III.3 (i.e. FHV, IHV, THV), one after another ${ }^{8}$. Given the recent concerns about research using panel data, (e.g. Thompson, 2009; Petersen, 2009; Gow et al., 2010), I use the standard errors that are robust across both time and firm dimensions.

\footnotetext{
${ }^{8}$ Note that as $\mathrm{k}$ varies, SUSPECT is fixed at time $t-1$ to allow the investigation of how current high valuation affect future real operation management controlling for factors measured contemporaneously with real operation management activities.
} 
The results are reported in Table $4^{9}$. Columns 12 to 16 show that across year $t$ to $t+4$, the coefficients on THV appear insignificant when Ab_CF is the dependent variable (Panel A). However, when the dependent is Ab_DEX or Ab_PROD, the coefficients on THV are significantly negative consistently across the five-year window consider. In year $t$, Ab_DEX of THV firms are lower than the rest of the sample by 0.134 , which is statistically significant at the $1 \%$ level and economically significant given the median scaled discretionary expenses of the whole sample is only 0.329 (see Table 1 ). In years $t+1$ to $t+4$, although the differences are smaller, Ab_DEX of THV firms are still significantly lower than that of the rest of the sample, ranging from 0.067 to 0.083 . Similarly, Ab_PROD of THV firms are much lower than the rest (ranging from 0.055 to 0.092 while the median of the whole sample is 0.793 ). Consequently, when aggregated into a composite measure, SRM_TOTAL seems to be negatively affected by THV. The evidence, therefore, suggests that firms manage earnings downwards in five years after being highly valued using discretionary expenses and production manipulation, which is in supports of $H 1 .^{10}$

\section{[INSERT TABLE 4 HERE]}

It is interesting to note that while signalling to correct market high valuation, firms prefer using discretionary expenses and production manipulation to managing sales. Although by definition, deviation from any optimal business decision is costly, it could be argued that sales manipulation has more negative effects. To depress earnings via sales manipulation, firms need to stricter sales policies, which could consequently lead to lost of customers in long-term. In comparison with sales manipulation, the consequences of spending more

\footnotetext{
${ }^{9}$ For the sake of compact presentation, Table 4 only reports the estimated coefficients and t-statistics for SUSPECT. Most of the coefficients on the control variables are statistically significant and have the predicted signs. The full results are available upon requests.

${ }^{10}$ Since there are quite a few control variables, an immediate concern is multicollinearity. Although Table 2 shows that there is no considerable correlation between the right hand side variables, I can further mitigate the concern. In untabulated results when I re-estimate equation (5) using only aSIZE, VB and $a R O A$ as control variables, the main conclusions of this paper are qualitatively the same (while the adjusted $R^{2}$ s drop considerably).
} 
discretionary expenses and underproduction is less severe (at least most of discretionary expenses could create some future benefits). Therefore, manager behaviours in this case, conditional on the motivations to depress earnings via real operation, are still in line with a value maximization function.

On the surface, the evidence seems to be in contrast to Jensen's (2005) agency costs theory, which predicts an upward earnings management by substantially overvalued firms. However, as argued earlier, my test has little to say about Jensen's story because I investigate highly valued firms rather than substantially overvalued firms. Highly valued firms probably still have the chance to escape from being more highly valued while substantially overvalued firms are more likely to be trapped within the "game" of cooking the books to justify the unachievable market expectations. Nevertheless, even when I do not directly test Jensen's hypothesis, it is necessary to explain my evidence under the lights of previous studies that document an income-increasing accruals management engaged by highly valued firms (e.g. Houmes and Skantz, 2010, Chi and Gupta, 2009). As explained earlier, in comparison with accruals management, I would argue that real operation management behaviours better represent managers' real intention in long-term equilibrium (because accruals will eventually reverse, it could not be used consistently in long-term). Therefore, my consistent evidence of income-decreasing real operation management, taken together with the upward accruals management documented elsewhere, is consistent with the scenario where highly valued firms strategically manage earnings to correct the market in long-term (by depressing earnings through real operation management) but try to avoid a sudden correction in year $t$ (by engaging in upward accruals management) ${ }^{11}$. This story is intuitive because being overvalued in long-term is quite dangerous for both the firms and the

\footnotetext{
${ }^{11}$ In unreported results, I estimate this regression: $A b_{-} A C_{i, t+k}=\alpha+\beta_{1}\left(a S I Z E_{i, t-1+k}\right)+\beta_{2}\left(V B_{i, t-1+k}\right)+$ $\beta_{3}\left(a R O A_{i, t+k}\right)+\beta_{4}\left(a L E V_{i, t-1+k}\right)+\beta_{5}\left(\right.$ aBLOAT $\left._{i, t-1+k}\right)+\beta_{6}\left(\operatorname{LOSS}_{-} F I R M_{i, t+k}\right)+\beta_{7}\left(\right.$ LOSS $\left._{-} I N D_{i, t+k}\right)+$ $\beta_{8}\left(S E O_{i, t+k}\right)+\beta_{9}\left(A b_{-} I N V_{i, t+k}\right)+\beta_{10}\left(\operatorname{SUSPECT}_{i, t-1}\right)+\varepsilon_{i, t+k}$; where: $\mathrm{k}=0,1,2,3$, 4; SUSPECT is replaced by FHV, IHV, THV, one after the other. The results confirm that highly valued firms only manipulate accruals upwards in year $t$ and do not engage in accruals management in long-term. Details are available upon requests.
} 
managers, but a sudden price drop is often so painful that most managers would avoid if possible.

Columns 2 to 11 report similar analyses when THV is decomposed into FHV and IHV. The coefficients on FHV are consistently significant and negative across the years considered when Ab_DEX or Ab_PROD is the dependent variables. However, it is interesting to note that when IHV is used, although the coefficients on IHV are still consistently negative, the magnitudes are smaller and the statistical significance is weaker as compared to FHV. In fact, when SRM_TOTAL is the dependent variable, the coefficients on IHV are all insignificant, except only in year $t$ and $t+4$ (t-statistics are -1.959 and -1.830 , respectively). The evidence, therefore, suggests that highly valued firms manage earnings downwards in long-term, but they tend to be irresponsive if the high valuation is due to the market highly values the whole industry, which is in line with hypothesis $H 2$.

\section{IV.4. Robustness checks: Alternative indicators of highly valued firms}

The results reported in the main section could be misleading if the indicators of highly valued firms is deficient. This section will strengthen the evidence obtained in the main tests by providing evidence that the findings are robust when I use different approaches to identify highly valued firms.

In the main test, following Rhodes-Kropf et al. (2005) firm-specific intrinsic value is in effect estimated using a special form of the residual income valuation model under the assumptions that book values and net incomes grow at constant rates, where the growth rates and costs of equity are embodied by the risk characteristics of the average firm in a given industry-year. As an alternative to the residual income model, the first alternative indicator employs a simple relative valuation model to identify highly valued stocks. Each year, I pooled firms in the same two-digit SIC code together to have groups of "comparable" firms. Within each groups of "comparable" firms, the market-to-book ratio of the median firm is then used to estimate the firms' intrinsic values as follows: 


$$
R I V_{i, t}=\alpha_{j, t} \times B V_{i, t}
$$

where: $R I V_{i, t}$ is the relative valuation model's estimate of firm i's intrinsic value in year $t ; \alpha_{j, t}$ is the median market-to-book ratio of industry $j$ in year $t$, defined as market values as at fiscal year-end divided by book values of equity; $B V_{i, t}$ is book value of firm $i$ in year $t$.

The deviation of $R I V_{i, t}$ from the firm's actual market value (denoted as $R V E_{i, t}$ ) is then used to identify highly valued firms. Stocks whose $R V E_{i, t}$ are positive are ranked into five quintiles and the indicator $\mathrm{RHV}$ is defined as a dummy which takes the value of one if the stock is in the highest quintile, and zero otherwise. There are 198 firm-year observations defined as highly valued under this approach. I then re-estimate equation (5) with RHV replaced for SUSPECT and VB excluded from the right hand side (to avoid the problem of multicollinearity because by construct VB is a component of the market-to-book ratio, which in turn is the main input to define RHV).

Any ex ante indicator of highly valued firms could be subjected to potential errors. As a final check, the regression analysis is repeated with highly valued firms identified in hindsight. The 1995-2004 period examined in this paper includes the so-called bubble period in the late 1990s, in which firms in high-tech, internet and telecommunication industries are substantially highly valued leading to the bust in 2000 . I define the period 1995-1999 as the exaggerating period, during which high-tech, internet and telecommunication firms are becoming increasingly highly valued. Those firms are thus highly valued because the whole industry is overheated, not because the market misevaluates a specific firm. Therefore, the ex post indicator in this section is only suitable to test $H 2$.

Firms which are highly valued during the bubble period are identified as follows. First, following Waldron and Jordan (2010), I identify firms which belong to IT, biotechnology and telecommunication industries (SIC 7370-7380, 3570-3577, 2834-2836, 4813). Second, of the remained firms, those which are classified to software, telecommunication equipment, internet, semiconductors and biotechnology industries based on ICB Level 5 industry 
classification are also identified. Finally, I define EHV as a dummy variable which is one if an observation has one of the above two identifications and is in the period 1995-1999, and zero otherwise. There are 143 firm-year observations defined as highly valued using this approach. Equation (5) is then re-estimated using EHV as SUSPECT and without HERFINDAHL, LOSS_IND and DEX_BENEFIT (those industry-wide control variables need to be excluded to avoid the problem of multicollinearity because by construct EHV is industry-wide) on the right hand side.

For compact presentation, Table 5 only presents the estimated coefficients and t-statistics for the indicators of highly valued firms ${ }^{12}$. The results generally confirm most of the main findings in the main regression test. First, in columns 2 to 6 , the coefficients on RHV are consistently insignificant when Ab_CF is the dependent variable. When Ab_DEX or Ab_PROD is the dependent variable, the coefficients on RHV are consistently negative and significant (except only for when Ab_DEX in year $t$ is the dependent variable, it is still negative but insignificant with t-statistics of -1.319). Overall, the evidence strongly suggests that firms manage earnings downwards in up to five years after being highly valued using discretionary expenses and production manipulation, which provide further supports for $H 1$. Second, it could be observed from columns 7 to 11 that while the coefficients on EHV are negative quite consistently, they are statistically insignificant in most cases. The evidence, therefore, provides further supports for hypothesis $\mathrm{H} 2$ suggesting firms do not manipulate real operations if the market highly values the whole industry.

[INSERT TABLE 5 HERE]

\section{CONCLUSIONS}

This paper is the first study that investigates how firms manage real operations in five years after being highly valued. I hypothesize that in long-term highly valued firms would exercise

\footnotetext{
${ }^{12}$ The full results are available upon requests.
} 
income-decreasing real operation management in attempts to correct the market, and such behaviour is observable only when the mispricing is at firm-level rather than at industry-level. Using a sample of UK listed stocks in the period from 1995 to 2004, I find interesting evidence which is consistent with the signalling hypothesis suggesting that highly valued firms manage earnings downwards as signals to correct the market. In particular, highly valued firms tend to spend more discretionary expenses and produce less as compared to others. Moreover, using the approach introduced by Rhodes-Kropf et al. (2005), the paper decomposes market misevaluation into firm-specific and industry-level components. The evidence reveals that while firm-specific market misevaluation seems to be a strong motivation for firms to manage real operations, highly valued firms appear irresponsive if the market highly prices the whole industry. Such conclusions are robust when a relative valuation model is used as well as when highly valued firms are identified in hindsight.

In a world where we could easily observe more and more multi-billion dollar failures of the big names who has been continuously highly appreciated by the market, a solution to the puzzle of how those overpriced firms operates and reacts to the market could potentially make a huge impact. Put under the lights of the existing evidence of upward accruals management in the year following firms being classified as highly valued (e.g. Chi and Gupta, 2009; Houmes and Skantz, 2010), my evidence provides an important missing piece of that puzzle. The whole picture is in line with a scenario where highly valued firms strategically manage earnings downwards via real operation management to correct the market in long-term while in short-term they temporarily inflate earnings via accruals management to try avoiding an immediate market correction.

The evidence in this paper has a number of interesting and significant contributions as well as useful implications. Investors, especially those who target mispriced stocks, should be aware that as the stocks become highly valued, subsequent earnings are probably depressed through real operation management, especially through more spending of discretionary expenses and underproduction. Such implication is also useful for the boards 
and audit committees in supervising the firm's real operations. For academics, the evidence has made a very important contribution to our general knowledge of capital market driven motivations for earnings management and to the specific field of whether and how mispriced securities are associated with earnings management. 


\section{Appendix: Definition of variables}

Ab_CF is Roychowdhury's (2006) abnormal cash flows, (estimated within each (two-digit SIC code) industry-year with at least 10 observations of available data excluding financial, utilities firms and firms with more than one type of ordinary shares) multiplied by -1 .

Ab_DEX is Roychowdhury's (2006) abnormal discretionary expenses (estimated within each (two-digit SIC code) industry-year with at least 10 observations of available data excluding financial, utilities firms and firms with more than one type of ordinary shares) multiplied by -1 .

Ab_PROD is Roychowdhury's (2006) abnormal production costs (estimated within each (two-digit SIC code) industry-year with at least 10 observations of available data excluding financial, utilities firms and firms with more than one type of ordinary shares).

SRM_TOTAL is total real operation management, measured as the sum of the standardized $A b \_C F, A b \_D E X$ and Ab_PROD, where the standardized variables are calculated as the deviation of the actual variables from the contemporaneous cross-sectional mean divided by the contemporaneous cross sectional standard deviation.

FVE is firm-specific valuation errors, measured as deviation of actual market values from firm-specific intrinsic values.

IVE is industry-level valuation errors, measured as deviation of firm-specific intrinsic values from industry-level intrinsic values.

TVE is total valuation errors, measured as sum of FVE and IVE.

FHV is a dummy which is one if a firm is ranked in the highest quintile of all firms with positive FVE.

IHV is a dummy which is one if a firm is ranked in the highest quintile of all firms with positive IVE.

THV is a dummy which is one if a firm is ranked in the highest quintile of all firms with positive TVE.

aSIZE is deviation from the corresponding industry-year median of log of market values at fiscal year-end.

VB is value-to-book ratio, defined as industry-level intrinsic values minus log of book values.

aROA is deviation from the corresponding industry-year median of the ratio of net incomes to beginning total assets.

aLEV is deviation from the corresponding industry-year median of the ratio of total liabilities to total assets.

aBLOAT is deviation from the corresponding industry-year median of BLOAT, where BLOAT is measured as shareholder's equity plus total debts minus cash and short-term investment scaled by sales.

M_SHARE is percentage of a firm's sales to the total sales of its industry.

HERFINDAHL is sum of squared market share of all firms in an industry, where market share of a firm is its sales scaled by the total sales of its industry.

DISTRESS is one if a firm's lagged Z_SCORE is negative and zero otherwise, where $Z \_S C O R E=3.2+12.8 x_{1}+2.5 x_{2}-10.68 x_{3}+0.029 x_{4} \quad\left(x_{1}\right.$ is pre-tax incomes scaled by current liabilities; $x_{2}$ is current assets scaled by total liabilities; $x_{3}$ is current liabilities scaled by total assets; $x_{4}$ is no-credit interval, measured as quick assets minus current liabilities scaled by daily operating expenses, where daily operating expenses is sales minus pre-tax incomes minus depreciation expenses divided by 365 ). 
LOSS_FIRM is one if a firm's net income is negative and zero otherwise.

LOSS_IND is one if the average net income of all firms in an industry is negative, and zero otherwise.

SEO is one if the firm issues common equity in the last three years (including the current year), and zero otherwise, where a common equity issuance is identified when (i) proceeds from sale/issuing stocks are positive, and (ii) number of outstanding common shares increases by at least $1 \%$ since last fiscal year.

aPPE_SALES is deviation from the corresponding industry-year median of the ratio of net plant, property and equipment to sales.

INV is investments, measured as capital expenditures plus research and development expenses minus proceeds received from fixed assets sales.

SLACK is ratio of cash and short-term investment to net property, plant and equipment.

Ab_INV is abnormal investment, measured as deviation from predicted values of the following equation, using the corresponding coefficients estimated within each (two-digit SIC code) industry-year with at least 10 observations of available data excluding financial, utilities firms and firms with more than one type of ordinary shares:

$$
I N V_{i, t} / A_{i, t-1}=\alpha+\beta_{1} V B_{i, t-1}+\beta_{2} L E V_{i, t-1}+\beta_{3} S L A C K_{i, t-1}+\beta_{4} C F O_{i, t} / A_{i, t-1}+\varepsilon_{i, t}
$$

OI is operating incomes before depreciation, research and development and selling and general administrative expenses.

CDEX $_{\mathbf{i}, \mathbf{t}-\mathbf{5} \text { to } \mathrm{t}}$ is the accumulation of scaled discretionary expenses in the last six years including the current year.

DEX_BENEFT is the coefficient on $\mathrm{CDEX}_{\mathrm{i}, \mathrm{t}-5 \text { to } t}$ in the following regression, which is run within each (two-digit SIC code) industry-year with at least 10 observations of available data excluding financial, utilities firms and firms with more than one type of ordinary shares:

$$
O I_{i, t} / R E V_{i, t}=\alpha+\beta_{1} A_{i, t-1} / R E V_{i, t-1}+\beta_{2} C D E X_{i, t-5} \text { to } t+\varepsilon_{i, t}
$$

RIV is relative valuation model's intrinsic values, measured as the median market-to-book ratio of the corresponding industry-year multiplied by the firm's book value, where market-tobook ratio is calculated as market values at fiscal year-end divided by book values of equity.

RVE is relative valuation model's valuation errors, measured as deviation of actual market value from RIV.

RHV is a dummy which is one if a firm is ranked in the highest quintile of all firms with positive RVE.

EHV is a dummy which is one if a firm is in SIC 7370-7380, 3570-3577, 2834-2836, 4813 industries or is classified to software, telecommunication equipment, internet, semiconductors and biotechnology industries based on ICB Level 5 industry classification, and the observation is in the period 1995-1999, and zero otherwise. 


\section{References}

Agarwal, V., and R. J. Taffler (2007), 'Twenty-five years of the taffler z-score model: Does it really have predictive ability?', Accounting \& Business Research,Vol. 37, No. 4, pp. 285-300.

Athanasakou, V. E., N. C. Strong, and M. Walker (2009a), 'Earnings management or forecast guidance to meet analyst expectations?', Accounting \& Business Research,Vol. 39, No. 1, pp. 3-35.

Athanasakou, V. E., N. C. Strong, and M. Walker (2009b), 'The market reward for achieving analyst earnings expectations: Does expectations or earnings management matter?', Available at SSRN: http://ssrn.com/abstract=1021949.

Badertscher, B. (2008), 'Overvaluation and its effect on management's choice of alternative earnings management mechanisms', Working Paper, University of Notre Dame.

Barton, J., and P. J. Simko (2002), 'The balance sheet as an earnings management constraint', Accounting Review,Vol. 77, No. 4, pp. 1-27.

Biddle, G. C., G. Hilary, and R. Verdi (2009), 'How does financial reporting quality relate to investment efficiency?', Available at SSRN: http://ssrn.com/abstract=1146536.

Chi, J., and M. Gupta (2009), 'Overvaluation and earnings management', Journal of Banking \& Finance, Vol. 33, No. 9, pp. 1652-1663.

Christensen, T. E., G. H. Paik, and E. K. Stice (2008), 'Creating a bigger bath using the deferred tax valuation allowance', Journal of Business Finance \& Accounting,Vol. 35, No. 5/6, pp. 601-625.

Cohen, D. A., A. Dey, and T. Z. Lys (2008), 'Real and accrual-based earnings management in the preand post-sarbanes-oxley periods', Accounting Review, Vol. 83, No. 3, pp. 757-787.

Cohen, D. A., and P. Zarowin (2008), 'Economic consequences of real and accrual-based earnings management activities', Working Paper, New York University.

Cohen, D. A., and P. Zarowin (2010), 'Accrual-based and real earnings management activities around seasoned equity offerings', Journal of Accounting \& Economics, Vol. 50, No. 1, pp. 2-19.

Dechow, P. M., R. G. Sloan, and A. P. Sweeney (1995), 'Detecting earnings management', Accounting Review,Vol. 70, No. 2, pp. 193-225.

Gore, P., P. F. Pope, and A. K. Singh (2007), 'Earnings management and the distribution of earnings relative to targets: Uk evidence', Accounting \& Business Research,Vol. 37, No. 2, pp. 123-149.

Gow, I. D., G. Ormazabal, and D. J. Taylor (2010), 'Correcting for cross-sectional and time-series dependence in accounting research', Accounting Review, Vol. 85, No. 2, pp. 483-512.

Graham, J. R., C. R. Harvey, and S. Rajgopal (2005), 'The economic implications of corporate financial reporting', Journal of Accounting \& Economics, Vol. 40, No. 1-3, pp. 3-73.

Green, J. P., A. W. Stark, and H. M. Thomas (1996), 'Uk evidence on the market valuation of research and development expenditures', Journal of Business Finance \& Accounting,Vol. 23, No. 2, pp. 191-216.

Gunny, K. (2009), 'The relation between earnings management using real activities manipulation and future performance: Evidence from meeting earnings benchmarks', Available at SSRN: http://ssrn.com/abstract $=816025$.

Houmes, R. E., and T. R. Skantz (2010), 'Highly valued equity and discretionary accruals', Journal of Business Finance \& Accounting, Vol. 37, No. 1/2, pp. 60-92.

Jensen, M. C. (2005), 'Agency costs of overvalued equity', Financial Management, Vol. 34, No. 1, pp. 5-19.

Kedia, S., and T. Philippon (2009), 'The economics of fraudulent accounting', Review of Financial Studies, Vol. 22, No. 6, pp. 2169-2199.

Lara, J. M. G., B. G. Osma, and E. Neophytou (2009), 'Earnings quality in ex-post failed firms', Accounting \& Business Research, Vol. 39, No. 2, pp. 119-138.

Lev, B., and T. Sougiannis (1996), 'The capitalization, amortization, and value-relevance of $r \& d$ ', Journal of Accounting \& Economics,Vol. 21, No. 1, pp. 107-138.

Loughran, T., and J. R. Ritter (1995), 'The new issues puzzle', Journal of Finance,Vol. 50, No. 1, pp. $23-$ 51. 
Madhogarhia, P., N. K. Sutton, and T. Kohers (2009), 'Earnings management practices among growth and value firms', Applied Financial Economics,Vol. 19, No. 22, pp. 1767-1778.

McNichols, M. F., and S. R. Stubben (2008), 'Does earnings management affect firms' investment decisions?', Accounting Review,Vol. 83, No. 6, pp. 1571-1603.

Perry, S. E., and T. H. Williams (1994), 'Earnings management preceding management buyout offers', Journal of Accounting \& Economics,Vol. 18, No. 2, pp. 157-179.

Petersen, M. A. (2009), 'Estimating standard errors in finance panel data sets: Comparing approaches', Review of Financial Studies,Vol. 22, No. 1, pp. 435-480.

Rhodes-Kropf, M., D. T. Robinson, and S. Viswanathan (2005), 'Valuation waves and merger activity: The empirical evidence', Journal of Financial Economics,Vol. 77, No. 3, pp. 561-603.

Ronen, J., and V. Yaari (2008), Earnings management: Emerging insights in theory, practice, and research, (Springer, New York).

Roychowdhury, S. (2006), 'Earnings management through real activities manipulation', Journal of Accounting \& Economics, Vol. 42, No. 3, pp. 335.

Sawicki, J., and K. Shrestha (2008), 'Insider trading and earnings management', Journal of Business Finance \& Accounting, Vol. 35, No. 3, pp. 331-346.

Skinner, D. J., and R. G. Sloan (2002), 'Earnings surprises, growth expectations, and stock returns or don't let an earnings torpedo sink your portfolio', Review of Accounting Studies, Vol. 7, No. 2/3, pp. 289-312.

Subramanyam, K. R. (1996), 'The pricing of discretionary accruals', Journal of Accounting \& Economics, Vol. 22, No. 1-3, pp. 249-281.

Taffler, R. (1983), 'The assessment of company solvency and performance using a statistical model', Accounting \& Business Research,Vol. 13, No. 52, pp. 295-307.

Teoh, S. H., W. Ivo, and T. J. Wong (1998a), 'Earnings management and the long-run market performance of initial public offerings', Journal of Finance, Vol. 53, No. 6, pp. 1935-1974.

Teoh, S. H., I. Welch, and T. J. Wong (1998b), 'Earnings management and the underperformance of seasoned equity offerings', Journal of Financial Economics, Vol. 50, No. 1, pp. 63-99.

Thompson, S. (2009), 'Simple formulas for standard errors that cluster by both firm and time', Available at SSRN: http://ssrn.com/abstract=914002.

Waldron, M. A., and C. E. Jordan (2010), 'The comparative predictive abilities of accrual earnings and cash flows in periods of economic turbulence: The case of the it bubble', Journal of Applied Business Research,Vol. 26, No. 1, pp. 85-97.

Watts, R. L., and J. L. Zimmerman (1990), 'Positive accounting theory: A ten year perspective', Accounting Review, Vol. 65, No. 1, pp. 131-156.

Zang, A. Y. (2007), 'Evidence on the tradeoff between real manipulation and accrual manipulation', Available at SSRN: http://ssrn.com/abstract=961293. 


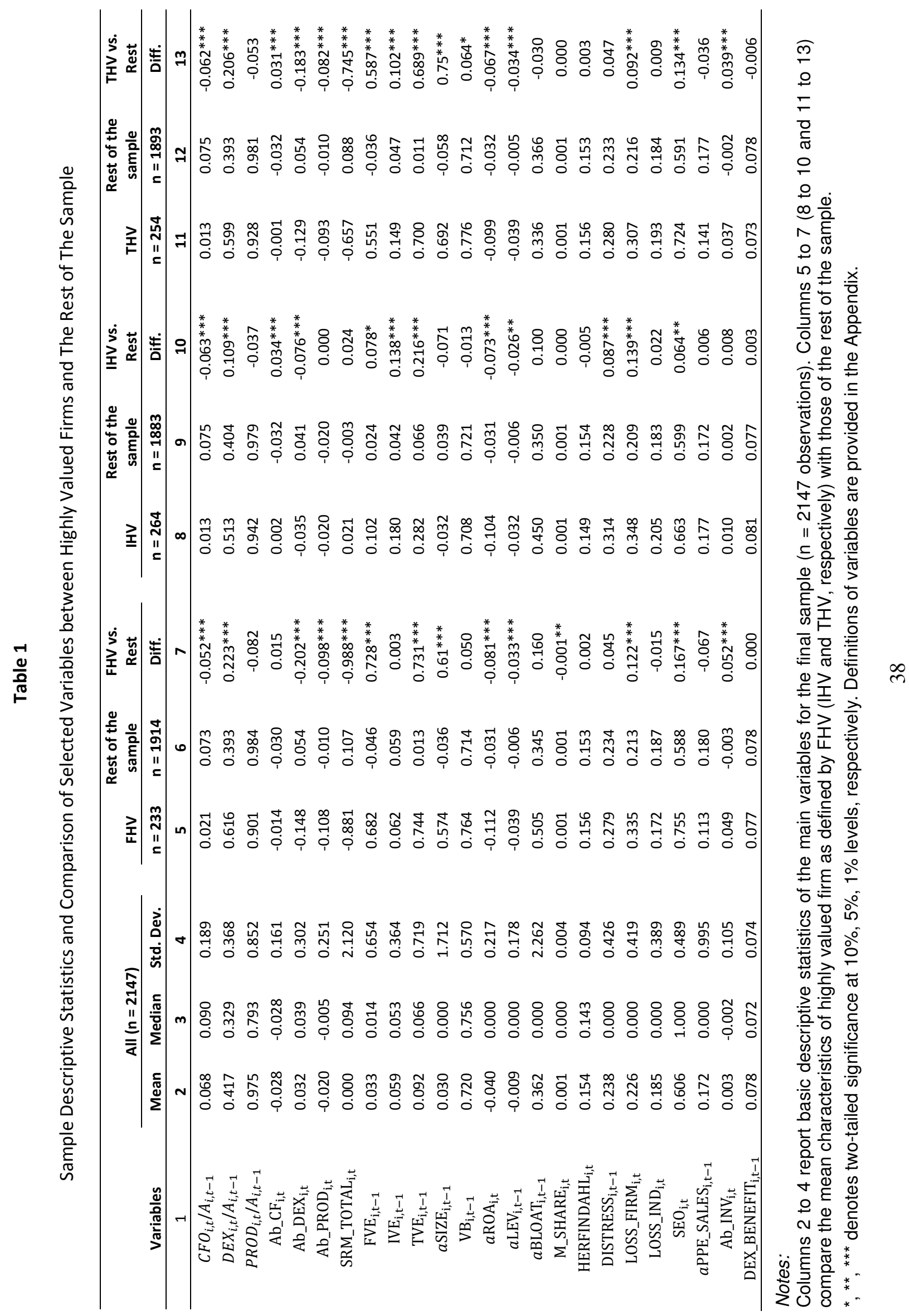




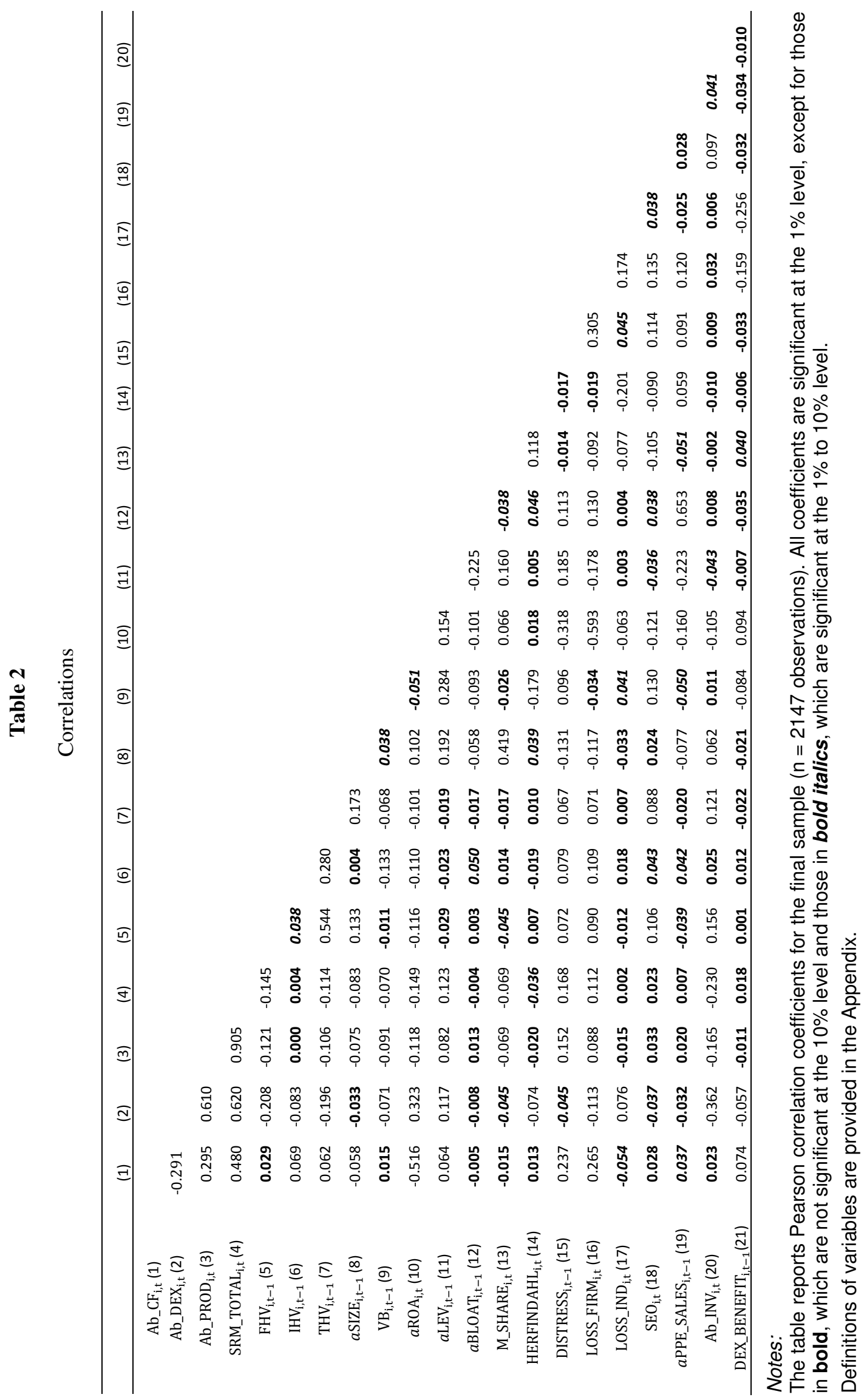


Table 3

Proxies for Real Operation Management in Five Years after Market Valuation Measurement across Groups Ranked by Firm-Specific, Industry-Level and Total Valuation Errors

\begin{tabular}{|c|c|c|c|c|c|c|c|c|c|c|}
\hline & $\begin{array}{c}\text { Group } \\
1\end{array}$ & $\begin{array}{c}\text { Group } \\
2 \\
\end{array}$ & $\begin{array}{c}\text { Group } \\
\mathbf{3}\end{array}$ & $\begin{array}{c}\text { Group } \\
4\end{array}$ & $\begin{array}{c}\text { Group } \\
5\end{array}$ & $\begin{array}{c}\text { Group } \\
6\end{array}$ & $\begin{array}{c}\text { Group } \\
7\end{array}$ & $\begin{array}{c}\text { Group } \\
8 \\
\end{array}$ & $\begin{array}{c}\text { Group } \\
9\end{array}$ & $\begin{array}{c}\text { Group } \\
10\end{array}$ \\
\hline \multicolumn{11}{|c|}{ Panel A: Ranked by firm-specific valuation errors } \\
\hline $\mathrm{Ab}_{-} \mathrm{CF}_{\mathrm{i}, \mathrm{t}}$ & -0.027 & -0.013 & -0.040 & -0.033 & -0.029 & -0.036 & -0.031 & -0.030 & -0.025 & -0.014 \\
\hline Ab_DEX $X_{i, t}$ & 0.115 & 0.097 & 0.093 & 0.087 & 0.054 & 0.049 & 0.055 & -0.006 & -0.030 & -0.148 \\
\hline $\mathrm{Ab}_{-} \mathrm{PROD}_{\mathrm{i}, \mathrm{t}}$ & 0.028 & 0.042 & 0.018 & 0.020 & -0.003 & -0.025 & -0.013 & -0.064 & -0.062 & -0.108 \\
\hline SRM_TOTAL $_{\mathrm{i}, \mathrm{t}}$ & 0.529 & 0.509 & 0.296 & 0.342 & 0.150 & 0.018 & 0.038 & -0.311 & -0.381 & -0.881 \\
\hline $\mathrm{Ab}_{-} \mathrm{CF}_{\mathrm{i}, \mathrm{t}+1}$ & -0.025 & -0.040 & -0.038 & -0.021 & -0.029 & -0.037 & -0.034 & -0.043 & -0.029 & -0.025 \\
\hline Ab_DEX $_{i, t+1}$ & 0.109 & 0.111 & 0.092 & 0.079 & 0.070 & 0.042 & 0.070 & 0.019 & 0.007 & -0.077 \\
\hline $\mathrm{Ab}_{-} \mathrm{PROD}_{\mathrm{i}, \mathrm{t}+1}$ & 0.021 & 0.030 & 0.010 & 0.017 & -0.006 & -0.014 & -0.009 & -0.053 & -0.053 & -0.091 \\
\hline SRM_TOTAL $_{\mathrm{i}, \mathrm{t}+\mathrm{t}}$ & 0.471 & 0.361 & 0.248 & 0.379 & 0.159 & -0.041 & 0.071 & -0.336 & -0.333 & -0.705 \\
\hline $\mathrm{Ab}_{-} \mathrm{CF}_{\mathrm{i}, \mathrm{t}+2}$ & -0.022 & -0.036 & -0.037 & -0.036 & -0.036 & -0.035 & -0.036 & -0.048 & -0.037 & -0.039 \\
\hline Ab_DEX $_{\mathrm{i}, \mathrm{t}+2}$ & 0.106 & 0.107 & 0.088 & 0.100 & 0.096 & 0.057 & 0.073 & 0.050 & 0.011 & -0.066 \\
\hline $\mathrm{Ab}_{-} \mathrm{PROD}_{\mathrm{i}, \mathrm{t}+2}$ & 0.047 & 0.017 & 0.017 & 0.031 & 0.000 & -0.019 & -0.002 & -0.023 & -0.054 & -0.098 \\
\hline SRM_TOTAL $_{\mathrm{i}, \mathrm{t}+2}$ & 0.548 & 0.312 & 0.229 & 0.359 & 0.199 & -0.023 & 0.075 & -0.187 & -0.399 & -0.842 \\
\hline $\mathrm{Ab}_{-} \mathrm{CF}_{\mathrm{i}, \mathrm{t}+3}$ & -0.023 & -0.030 & -0.037 & -0.034 & -0.029 & -0.044 & -0.044 & -0.042 & -0.032 & -0.037 \\
\hline Ab_DEX $_{\mathrm{i}, \mathrm{t}+3}$ & 0.115 & 0.114 & 0.100 & 0.098 & 0.096 & 0.068 & 0.073 & 0.036 & 0.006 & -0.056 \\
\hline $\mathrm{Ab}_{-} \mathrm{PROD}_{\mathrm{i}, \mathrm{t}+3}$ & 0.048 & 0.056 & 0.032 & 0.007 & 0.010 & -0.013 & 0.013 & -0.037 & -0.051 & -0.098 \\
\hline SRM_TOTAL $_{\mathrm{i}, \mathrm{t}+3}$ & 0.572 & 0.480 & 0.292 & 0.230 & 0.240 & -0.077 & 0.052 & -0.278 & -0.406 & -0.806 \\
\hline Ab_CF $F_{i, t+4}$ & -0.023 & -0.024 & -0.033 & -0.035 & -0.035 & -0.026 & -0.047 & -0.049 & -0.048 & -0.028 \\
\hline Ab_DEX $_{\mathrm{i}, \mathrm{t}+4}$ & 0.119 & 0.117 & 0.109 & 0.096 & 0.106 & 0.068 & 0.077 & 0.054 & 0.023 & -0.061 \\
\hline $\mathrm{Ab}_{-} \mathrm{PROD}_{\mathrm{i}, \mathrm{t}+4}$ & 0.057 & 0.055 & 0.041 & 0.019 & 0.015 & -0.005 & 0.004 & -0.028 & -0.041 & -0.088 \\
\hline SRM_TOTAL $_{\mathrm{i}, \mathrm{t}+4}$ & 0.564 & 0.462 & 0.336 & 0.206 & 0.208 & 0.048 & -0.054 & -0.279 & -0.438 & -0.767 \\
\hline \multicolumn{11}{|c|}{ Panel B: Ranked by industry-level valuation errors } \\
\hline $\mathrm{Ab}_{-} \mathrm{CF}_{\mathrm{i}, \mathrm{t}}$ & -0.014 & -0.021 & -0.018 & -0.021 & -0.029 & -0.027 & -0.046 & -0.047 & -0.043 & 0.002 \\
\hline $\mathrm{Ab}_{-} \mathrm{DEX} \mathrm{X}_{\mathrm{i}, \mathrm{t}}$ & -0.007 & 0.009 & 0.053 & 0.038 & 0.047 & 0.052 & 0.051 & 0.043 & 0.061 & -0.035 \\
\hline $\mathrm{Ab}_{-} \mathrm{PROD}_{\mathrm{i}, \mathrm{t}}$ & -0.024 & -0.026 & 0.011 & -0.030 & -0.012 & -0.023 & -0.029 & -0.020 & -0.023 & -0.020 \\
\hline SRM_TOTAL $_{\mathrm{i}, \mathrm{t}}$ & -0.120 & -0.067 & 0.193 & 0.031 & -0.004 & 0.078 & -0.064 & -0.061 & 0.009 & 0.021 \\
\hline $\mathrm{Ab}_{-} \mathrm{CF}_{\mathrm{i}, \mathrm{t}+1}$ & -0.013 & -0.025 & -0.039 & -0.032 & -0.035 & -0.027 & -0.034 & -0.036 & -0.046 & -0.031 \\
\hline Ab_DEX $X_{i, t+1}$ & 0.000 & 0.004 & 0.089 & 0.061 & 0.063 & 0.073 & 0.052 & 0.052 & 0.069 & 0.013 \\
\hline $\mathrm{Ab}_{-} \mathrm{PROD} \mathrm{D}_{\mathrm{i}, \mathrm{t}+1}$ & -0.019 & -0.035 & 0.022 & -0.015 & -0.009 & 0.003 & -0.018 & -0.033 & -0.025 & -0.034 \\
\hline SRM_TOTAL $_{\mathrm{i}, \mathrm{t}+1}$ & -0.096 & -0.207 & 0.207 & -0.005 & -0.038 & 0.235 & 0.006 & 0.005 & -0.026 & -0.126 \\
\hline $\mathrm{Ab}_{-} \mathrm{CF}_{\mathrm{i}, \mathrm{t}+2}$ & -0.035 & -0.038 & -0.023 & -0.052 & -0.051 & -0.029 & -0.040 & -0.043 & -0.044 & -0.016 \\
\hline Ab_DEX $_{\mathrm{i}, \mathrm{t}+2}$ & 0.017 & 0.034 & 0.082 & 0.076 & 0.075 & 0.090 & 0.057 & 0.062 & 0.080 & 0.011 \\
\hline Ab_PROD $_{\mathrm{i}, \mathrm{t}+2}$ & -0.021 & -0.025 & 0.027 & -0.002 & -0.001 & 0.001 & -0.015 & -0.037 & -0.008 & -0.018 \\
\hline SRM_TOTAL $_{\mathrm{i}, \mathrm{t}+2}$ & -0.185 & -0.114 & 0.320 & -0.016 & -0.038 & 0.199 & -0.053 & -0.129 & 0.031 & -0.021 \\
\hline $\mathrm{Ab} \_\mathrm{CF}_{\mathrm{i}, \mathrm{t}+3}$ & -0.012 & -0.034 & -0.033 & -0.057 & -0.042 & -0.030 & -0.033 & -0.051 & -0.043 & -0.020 \\
\hline Ab_DEX $_{\mathrm{i}, \mathrm{t}+3}$ & 0.011 & 0.021 & 0.095 & 0.089 & 0.069 & 0.092 & 0.070 & 0.063 & 0.090 & 0.008 \\
\hline $\mathrm{Ab}_{-} \mathrm{PROD}_{\mathrm{i}, \mathrm{t}+3}$ & -0.020 & -0.034 & 0.040 & -0.002 & -0.012 & 0.010 & 0.005 & -0.020 & -0.009 & -0.020 \\
\hline SRM_TOTAL $_{\mathrm{i}, \mathrm{t}+3}$ & -0.075 & -0.179 & 0.298 & -0.043 & -0.057 & 0.210 & 0.078 & -0.157 & 0.021 & -0.110 \\
\hline $\mathrm{Ab}_{-} \mathrm{CF}_{\mathrm{i}, \mathrm{t}+4}$ & -0.012 & -0.053 & -0.037 & -0.050 & -0.035 & -0.025 & -0.021 & -0.053 & -0.043 & -0.029 \\
\hline Ab_DEX $\mathrm{i}_{\mathrm{i}, \mathrm{t}+4}$ & 0.020 & 0.020 & 0.105 & 0.086 & 0.074 & 0.094 & 0.075 & 0.084 & 0.092 & 0.011 \\
\hline Ab_PROD $_{i, t+4}$ & -0.008 & -0.018 & 0.029 & -0.012 & 0.003 & 0.019 & 0.009 & -0.005 & -0.008 & -0.012 \\
\hline SRM_TOTAL $_{\mathrm{i}, \mathrm{t}+4}$ & 0.014 & -0.283 & 0.232 & -0.050 & 0.012 & 0.250 & 0.117 & -0.109 & -0.016 & -0.191 \\
\hline
\end{tabular}


Table 3 (continued)

\begin{tabular}{|c|c|c|c|c|c|c|c|c|c|c|}
\hline & $\begin{array}{c}\text { Group } \\
1\end{array}$ & $\begin{array}{c}\text { Group } \\
2\end{array}$ & $\begin{array}{c}\text { Group } \\
\mathbf{3}\end{array}$ & $\begin{array}{c}\text { Group } \\
4\end{array}$ & $\begin{array}{c}\text { Group } \\
5\end{array}$ & $\begin{array}{c}\text { Group } \\
6\end{array}$ & $\begin{array}{c}\text { Group } \\
7\end{array}$ & $\begin{array}{c}\text { Group } \\
8\end{array}$ & $\begin{array}{c}\text { Group } \\
9\end{array}$ & $\begin{array}{c}\text { Group } \\
10\end{array}$ \\
\hline \multicolumn{11}{|c|}{ Panel C: Ranked by total valuation errors } \\
\hline $\mathrm{Ab}_{-} \mathrm{CF}_{\mathrm{i}, \mathrm{t}}$ & -0.031 & -0.033 & -0.024 & -0.024 & -0.030 & -0.036 & -0.034 & -0.039 & -0.028 & -0.001 \\
\hline Ab_DEX $_{\mathrm{i}, \mathrm{t}}$ & 0.111 & 0.081 & 0.084 & 0.103 & 0.076 & 0.059 & 0.059 & 0.006 & -0.041 & -0.129 \\
\hline $\mathrm{Ab}_{-} \mathrm{PROD} \mathrm{D}_{\mathrm{i}, \mathrm{t}}$ & 0.028 & 0.025 & 0.012 & 0.031 & 0.007 & -0.022 & -0.019 & -0.049 & -0.059 & -0.093 \\
\hline SRM_TOTAL $_{\mathrm{i}, \mathrm{t}}$ & 0.439 & 0.320 & 0.280 & 0.444 & 0.288 & 0.030 & 0.070 & -0.233 & -0.439 & -0.657 \\
\hline $\mathrm{Ab}_{-} \mathrm{CF}_{\mathrm{i}, \mathrm{t}+1}$ & -0.022 & -0.039 & -0.031 & -0.034 & -0.038 & -0.037 & -0.038 & -0.031 & -0.040 & -0.014 \\
\hline$A b \_D E X_{i, t+1}$ & 0.101 & 0.097 & 0.082 & 0.122 & 0.080 & 0.049 & 0.081 & 0.016 & -0.020 & -0.048 \\
\hline Ab_PROD $_{i, t+1}$ & 0.020 & 0.020 & 0.008 & 0.035 & 0.007 & -0.015 & -0.013 & -0.043 & -0.062 & -0.078 \\
\hline SRM_TOTAL $_{i, t+1}$ & 0.419 & 0.274 & 0.209 & 0.440 & 0.166 & 0.012 & 0.120 & -0.196 & -0.510 & -0.467 \\
\hline $\mathrm{Ab}_{-} \mathrm{CF}_{\mathrm{i}, \mathrm{t}+2}$ & -0.025 & -0.037 & -0.032 & -0.049 & -0.040 & -0.034 & -0.043 & -0.038 & -0.038 & -0.030 \\
\hline$A b \_D E X_{i, t+2}$ & 0.093 & 0.103 & 0.093 & 0.137 & 0.111 & 0.059 & 0.080 & 0.036 & -0.019 & -0.029 \\
\hline Ab_PROD $_{i, t+2}$ & 0.027 & 0.024 & 0.017 & 0.041 & 0.020 & -0.010 & -0.005 & -0.040 & -0.052 & -0.077 \\
\hline SRM_TOTAL $_{i, t+2}$ & 0.373 & 0.321 & 0.267 & 0.424 & 0.321 & 0.047 & 0.063 & -0.236 & -0.485 & -0.577 \\
\hline $\mathrm{Ab}_{-} \mathrm{CF}_{\mathrm{i}, \mathrm{t}+3}$ & -0.012 & -0.025 & -0.044 & -0.041 & -0.039 & -0.040 & -0.042 & -0.047 & -0.029 & -0.031 \\
\hline$A b \_D E X_{i, t+3}$ & 0.092 & 0.099 & 0.099 & 0.127 & 0.109 & 0.084 & 0.089 & 0.034 & -0.018 & -0.032 \\
\hline $\mathrm{Ab}_{-} \mathrm{PROD}_{\mathrm{i}, \mathrm{t}+3}$ & 0.046 & 0.051 & 0.019 & 0.024 & 0.023 & -0.003 & 0.004 & -0.035 & -0.055 & -0.077 \\
\hline SRM_TOTAL $_{i, t+3}$ & 0.498 & 0.484 & 0.188 & 0.342 & 0.251 & 0.061 & 0.102 & -0.305 & -0.470 & -0.597 \\
\hline $\mathrm{Ab}_{-} \mathrm{CF}_{\mathrm{i}, \mathrm{t}+4}$ & -0.022 & -0.037 & -0.024 & -0.039 & -0.030 & -0.046 & -0.030 & -0.049 & -0.022 & -0.046 \\
\hline$A b \_D E X_{i, t+4}$ & 0.103 & 0.116 & 0.103 & 0.132 & 0.109 & 0.085 & 0.092 & 0.039 & -0.014 & -0.022 \\
\hline $\mathrm{Ab}_{-} \mathrm{PROD}_{\mathrm{i}, \mathrm{t}+4}$ & 0.047 & 0.048 & 0.028 & 0.039 & 0.030 & -0.003 & 0.017 & -0.032 & -0.051 & -0.063 \\
\hline SRM_TOTAL $_{\mathrm{i}, \mathrm{t}+4}$ & 0.429 & 0.393 & 0.331 & 0.359 & 0.342 & -0.018 & 0.186 & -0.341 & -0.445 & -0.660 \\
\hline
\end{tabular}

Notes:

Within each industry-year, stocks with negative lagged FVE are ranked into five quintiles (indexed from 1 to 5) and those with positive lagged FVE are ranked into five separate quintiles (indexed from 6 to 10). Panel A reports mean values of the proxies for real operation management in five years after market valuation measurement across these ten groups. Panel $B$ and $C$ reports the same statistics, but with stocks ranked by IVE and TVE, respectively.

Definitions of variables are provided in the Appendix. 


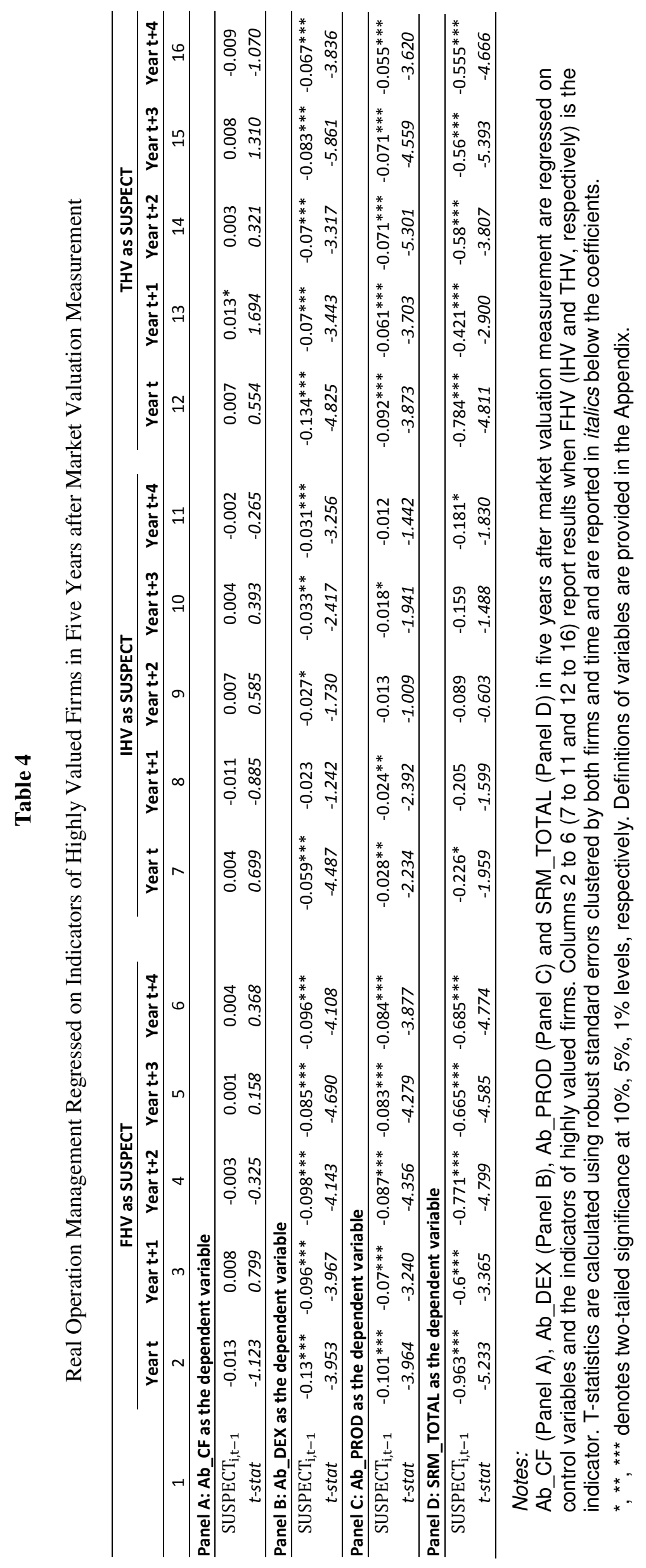




\section{Table 5}

Proxies for Real Operation Management Regressed on Control Variables and Relative ValuationBased and Ex Post Indicators of Highly Valued Firms in Five Years after Market Valuation Measurement

\begin{tabular}{|c|c|c|c|c|c|c|c|c|c|c|}
\hline & \multicolumn{5}{|c|}{ RHV as SUSPECT } & \multicolumn{5}{|c|}{ EHV as SUSPECT } \\
\hline & Year t & Year $t+1$ & Year $\mathbf{t + 2}$ & Year $t+3$ & Year $t+4$ & Year t & Year $t+1$ & Year $\mathbf{t}+2$ & Year $t+3$ & Year $t+4$ \\
\hline 1 & 2 & 3 & 4 & 5 & 6 & 7 & 8 & 9 & 10 & 11 \\
\hline \multicolumn{11}{|c|}{ Panel A: Ab_CF as dependent variable } \\
\hline SUSPECT $_{\mathrm{i}, \mathrm{t}-1}$ & -0.021 & -0.015 & -0.009 & 0.006 & -0.004 & -0.011 & $-0.044 * *$ & -0.022 & -0.019 & -0.022 \\
\hline t-stat & -1.300 & -1.279 & -0.737 & 0.561 & -0.360 & -0.815 & -2.156 & -1.484 & -1.078 & -1.025 \\
\hline \multicolumn{11}{|c|}{ Panel B: Ab_DEX as dependent variable } \\
\hline SUSPECT $_{\mathrm{i}, \mathrm{t}-1}$ & -0.042 & $-0.054 *$ & $-0.067 * * *$ & $-0.072 * *$ & $-0.077^{* *}$ & $-0.06 * *$ & 0.007 & -0.005 & -0.005 & -0.007 \\
\hline$t$-stat & -1.319 & -1.950 & -2.659 & -2.514 & -2.524 & -1.983 & 0.184 & -0.163 & -0.140 & -0.197 \\
\hline \multicolumn{11}{|c|}{ Panel C: Ab_PROD as dependent variable } \\
\hline SUSPECT $_{\mathrm{i}, \mathrm{t}-1}-$ & $-0.068 * * *$ & $-0.065 * *$ & $-0.063 * *$ & $-0.072 * *$ & $-0.061^{*}$ & $-0.055^{* *}$ & $-0.045^{*}$ & -0.04 & -0.034 & -0.031 \\
\hline t-stat & -2.656 & -2.157 & -2.209 & -2.550 & -1.893 & -2.233 & -1.953 & -1.064 & -1.088 & -0.923 \\
\hline \multicolumn{11}{|c|}{ Panel D: SRM_TOTAL as dependent variable } \\
\hline SUSPECT $_{i}$, & $-0.559 * * *$ & $-0.554 * *$ & $-0.592 * *$ & $-0.511^{* *}$ & $-0.519 * *$ & $-0.496 * *$ & $-0.465 * *$ & -0.376 & -0.36 & -0.421 \\
\hline t-stat & -2.596 & -2.209 & -2.408 & -2.248 & -2.219 & -1.968 & -2.049 & -1.418 & -1.368 & -1.360 \\
\hline
\end{tabular}

Notes:

Ab_CF (Panel A), Ab_DEX (Panel B), Ab_PROD (Panel C) and SRM_TOTAL (Panel D) in five years after market valuation measurement are regressed on control variables and RHV as the indicator of highly valued firms. Columns 2 to 6 (7 to 11) report the estimated coefficients, together with tstatistics, on when RHV (EHV) and adjusted $\mathrm{R}^{2}$. T-statistics are calculated using robust standard errors clustered by both firms and time and are reported in italics below the coefficients.

${ }^{*},{ }^{* *},{ }^{* * *}$ denotes two-tailed significance at $10 \%, 5 \%, 1 \%$ levels, respectively. Definitions of variables are provided in the Appendix. 
Figure 1: Proxies for real operations management in years $t$ to $t+4$ across groups ranked by firm-specific valuation errors at the end of year $t-1$
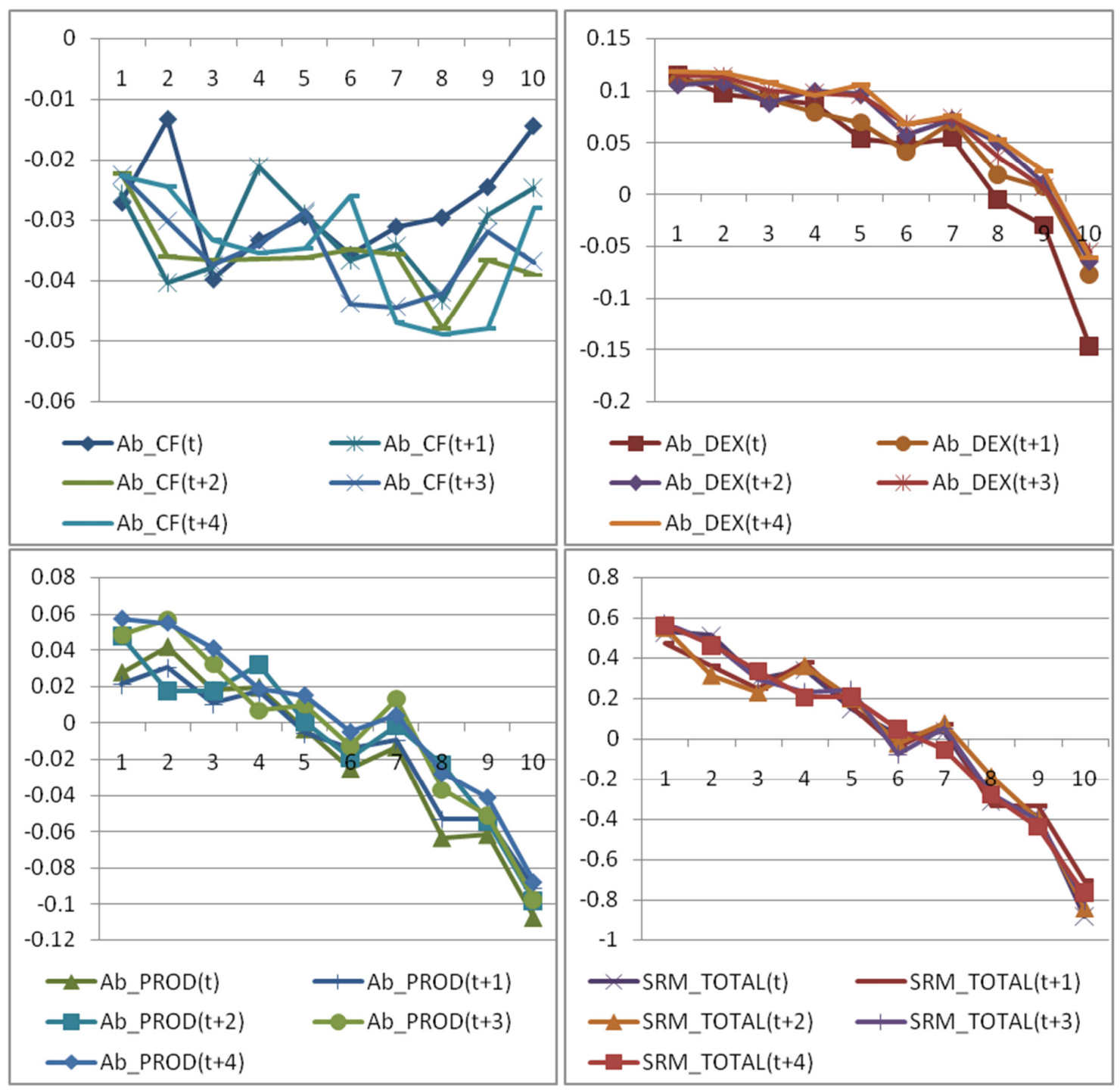